\title{
Exchange Rate Shocks and Firm Competitiveness in a Small, Export-Oriented Economy: The Case of Finland
}

\author{
Anand B. S. Gulati* \\ Hanken School of Economics, Finland \\ Johan Knif \\ Hanken School of Economics, Finland \\ James W. Kolari \\ Texas A\&M University, USA
}

This study empirically examines how exchange rate shocks affect firms' competitiveness in the small, export-oriented country of Finland. Specifically, using Sweden as a benchmark and controlling for cross-country sector and industry effects, the forex competition hypothesis is tested using the impact of exchange rate shocks on Finnish stock returns. The empirical tests reveal statistically significant exchange rate exposure of Finnish stock returns. Comparing pre- versus post-euro periods, equities' exchange rate exposure is much stronger after the introduction of the euro. Further results indicate that Finnish and Swedish sector and industry stock returns positively co-move. This implies market integration in contradiction to the forex competition hypothesis. However, for some sectors and industries interaction variables reveal that the

* Corresponding author. The authors received valuable comments and suggestions from an anonymous referee, Julian Gaspar, Seppo Pynnönen, Kenneth Högholm, Yrjö Koskinen, Edgar Ortiz, Mara Madaleno, Bernard Dumas, Chien-Hsiu Lin, and Bambang Irawan, as well as participants at the 2005 Graduate School of Finance (GSF) Finland winter workshop, the 2008 Multinational Financial Society (MFS) conference, the 2009 Global Financial Association (GFA) conference, the 2009 Paris Finance International Meeting (AFFI-EUROFIDAI), European Financial Management Association (EFMA) 2010 conference and Hanken Seminars. Also, we could not have completed this research without the financial and facilities support of the Center for International Business Studies in Mays Business School at Texas A\&M University, the Hanken Foundation, the Ella and Georg Ehrnrooth Foundation, and the Commerce and Industry Fund at Hanken. An earlier version of the study was presented at the 2009 Paris Finance International Meeting under a different title.

(Multinational Finance Journal, 2013, vol. 17, no. 1/2, pp. 1-47)

(C) Multinational Finance Society, a nonprofit corporation. All rights reserved.

DOI: $10.17578 / 17-1 / 2-1$ 
co-movement is conditional on exchange rate movements, especially in the post-euro period. Consequently, countries with small, open economies can be prone to exchange rate movements that (dis)advantage some firms relative to competing firms in other countries. (JEL: F15, F31, F36, G10, G11, G15)

Keywords: exchange rate exposure, stock returns, cross-country industry competition, market integration, pre- and post-euro.

\section{Introduction}

Do exchange rate movements of a country's currency affect the competitiveness of its firms? Financial news reports frequently discuss the perceived economic consequences of currency movements on firms' international competitiveness. At the present time, a stark reminder of the importance of this problem is slow economic growth and related debt crises in some European countries due to falling exports. It could be conjectured that, if some eurozone countries had not adopted the euro, depreciation or devaluation of their respective local currencies would tend to boost export competitiveness. Hereafter this conjecture is referred to as the forex competition hypothesis.

A major problem in testing the forex competition hypothesis is that exchange rates can have diverse impacts on firms' input costs, output prices, business risks, etc. According to Adler and Dumas (1980, 1983, 1984), a comprehensive approach for capturing complex exchange rate effects on firms is to estimate the sensitivity of firms' stock returns to exchange rate movements (i.e., exposure coefficient). While a large body of literature has investigated the significance of exchange rate exposure for equity returns ${ }^{1}$, few studies have examined the competitive effects of exchange rate movements on stock returns.

Closely related to the present study, Griffin and Stulz (2001) found that common shocks across industries in the U.S. and Japan were more important than exchange rate movements in explaining stock returns. Indeed, weekly exchange rate shocks explained little or no relative stock performance of industries. These and other results for large, industrial

1. For example, see Adler and Dumas (1983, 1984), Jorion (1990, 1991), Bartov and Bodnar (1994), De Santis and Gérard (1998), Dumas and Solnik (1995), He and Ng (1998), Vassalou (2000), Allayannis and Ihrig (2001), Bodnar and Wong (2003), Chen, Naylor and Lu (2004), Doidge, Griffin and Williamson (2006), Dominguez and Tesar (2006), Bartram (2007), Kolari, Moorman, and Sorescu (2008), and others. 
countries (i.e., Canada, the U.K., France, and Germany) led the authors to conclude that exchange rate shocks were not economically significant in explaining relative shareholder wealth effects across industries in competing countries. Likewise, based on forex exposure analyses of German investors within European countries, De Santis, Gerard and Hillion (2003) inferred that currency risks within Europe would have little economic impact (see also Sentana, 2002). By contrast, Williamson (2001) found significant exposure to exchange rate shocks among automotive firms in the U.S. and Japan. Time variation of exchange rate exposure as competitive conditions changed and variation in exposure among firms with different levels of foreign sales were consistent with the notion that multinational firms competing in global markets are sensitive to exchange rate movements. Additionally, based on evidence from eight non-U.S. countries, Dominguez and Tesar (2006) found that forex exposure was correlated with firm size, multinational status, foreign sales, international assets, and trade at the industry level. Unfortunately, only weak evidence of a link between international trade, competition, and exchange rate exposure on the firm level was found. Allayannis and Ihrig (2001) analyzed the cross-section of U.S. industries over time and indirectly examined the competitiveness issue. They found that 4-out-of-18 industries were significantly exposed to exchange-rate movements through the effect of industry competitive structure, export share, and imported input share. Moreover, Bodnar, Dumas and Marston (2002) also examined how exchange-rate exposures are associated with the competitive nature of export intensive Japanese industries. They developed a duopoly model of an exporting firm and solved it under the alternative assumptions of quantity and price competition to explain simultaneously the behavior of the prices of goods and the profits of a firm that competes with a local firm in a foreign market. Their model reveals the importance of the elasticity of substitution between home-produced and foreign-produced goods and market share. Empirical evidence confirmed that, as substitutability increased, keeping market share fixed, pass-through declined and exposure increased. Additionally, holding substitutability fixed, increases in market share reduced both pass-through and exposure elasticities. Bartram, Brown and Minton (2010), also analyzed the exposure puzzle by focusing on several aspects of exchange rate exposure. They examined the discrepancy between theoretical prediction that there should be sizable exchange rate (FX) exposure and the empirical research that has not been sufficiently able to document 
such exposure. In this regard, their empirical results exhibit that firms pass through a part of currency changes to customers and utilize both operation and financial hedges. They found that the firms they selected have a reduced exposure of $10-15 \%$ as a result of pass-through and operational hedging. Furthermore, a decrease of $40 \%$ of exposure had been found for firms that used financial hedging with foreign debt, and to some extent the use of FX derivatives. Hence, the combination of these factors has reduced an observable exchange rate exposure.

The present paper seeks to contribute new evidence on the forex competition hypothesis by examining evidence from Finland, a natural laboratory for testing due to its close competitive association with Sweden. Finland shares geographic proximity, similar industry structures, cross-border trade, and increasing company mergers with its neighbor Sweden. Both countries typically trade with the same countries within Europe, and many firms in Finland compete directly against counterparts in Sweden (e.g., the metal, forest \& paper, and information technology industries). Some examples of cross-country competition are: phone manufacturer Nokia in Finland versus Ericsson in Sweden, paper producers Stora Enso and UPM-Kymmene in Finland versus SCA and Holman in Sweden, and industrial Finnish companies Wartsila and Metso versus Swedish counterparts Atlas Copco and Sandvik. Therefore, the basis for the competitiveness hypothesis has been formed with regards to reduced exposure of exchange rate for the Finnish firms and possibility more advantages for Finnish firms. In this regard, this study uses different sectors and industries. It is expected that the exposure of exchange rate on the competitiveness levels are likely to be different in different sectors and industries, both in pre- and post-euro periods. In other words, there could be sectors integrations rather than competitiveness in the sense that positive coefficients of Swedish industry are obtained when regressed on Finnish industry as dependent variable along with the exchange rate. This paper compares the competitiveness of different sectors and industries in Finland and Sweden with respect to exchange rate movements. Also, both pre- and post-euro time periods are examined due to potential differential euro effects on the two countries' relative competitiveness. Finland joined the European Exchange Rate Mechanism (ERM) in 1996 and economic and monetary union (EMU) in 1999 by adopting the euro to replace the Finnish markka. By contrast, while Sweden joined the European Union (EU) in 1995, it continues to use the Swedish krona. Consequently, Sweden still sets its own monetary policy, including exchange rates, but 
Finland does not have similar privileges after joining the European single currency. Finally, because both countries are small, export-oriented economies, exchange rate movements are expected to be important to their firms and associated expected stock returns.

In brief, consistent with Finland's strong export orientation, the study finds that Finnish stock market returns increase in response to home currency depreciation. This exchange rate sensitivity increased considerably after Finland adopted the euro in 1999. Like Griffin and Stulz, this study finds that the excess stock returns of Finnish sectors and industries unconditionally co-move with counterpart Swedish excess stock returns, which imply integration rather than competitiveness. In this regard, after the euro was introduced, this integration tended to increase for some sectors and industries. Importantly, evidence on the co-movement of Finnish and Swedish excess stock returns conditional on exchange rate shocks and volatility tends to support forex sensitivity. That is, exchange rate movements appear to have affected Finnish stocks' returns relative to their Swedish counterparts in a number of industries and sectors, even after controlling for global stock market integration by using the MSCI world market index as a proxy. Indeed, the total marginal effects of Swedish excess stock returns on Finnish stock returns become negative in some industries implying competitiveness rather than integration, which lends support for the forex competition hypothesis. In conclusion, it seems that countries with small, open economies can be prone to exchange rate movements that (dis)advantage firms relative to competing firms in other countries.

This paper is organized as follows. Section II briefly reviews related literature on the euro. Section III presents the empirical methodology. Section IV describes the data. Section V reports the empirical results. Section VI concludes.

\section{Brief Literature Review}

A number of studies have sought to empirically document the economic and financial impacts of the 1999 introduction of the euro on European countries. This paper begins by overviewing European studies in general and then focuses on relevant Scandinavian studies in particular.

In a comprehensive study of European firms, confirming Mundell's (1961, 1973, 2000) views about optimum currency area benefits, 
Baldwin (2006) found that the euro increased trade among European countries by $5 \%$ to $15 \%$ (i.e., about $9 \%$ on average). Further investigating trade gains in Europe to determine whether they were asymmetrically distributed among euro nations with respect to their size, Badinger and Breuss (2009) found stronger gains among small nations. On average, the euro triggered a reallocation of intra-euro area exports to small countries of approximately $6 \% .{ }^{2}$ Another study by Bris, Koskinen and Nilsson (2006) examined the effect of the adoption of the euro as the common currency on corporate investment rates. Using data from 16 European countries, including the euro members (i.e., the European Monetary Union or EMU), they found that the euro increased investments for firms from countries that previously had weak currencies. Relatedly, Hardouvelis, Malliaropulos and Priestley (2006) ascertained that, in the second half of the 1990s, EMU stock markets became fully integrated. European integration was Eurozone specific (e.g., the United Kingdom showed no sign of increased integration with the EU stock market) and independent of possible simultaneous world market integration. Hence, they concluded that the euro was a driver of European stock market integration.

Further evidence by Bartram and Karolyi (2006) found that the euro decreased the volatility of trade-weighted exchange rates of European countries and was associated with a lower increase in stock market volatility in Europe compared to other countries. The latter reduction in market risk was primarily concentrated in firms with a high fraction of foreign sales or assets in Europe. Moreover, the euro led to a net absolute decrease in foreign exchange rate exposure of nonfinancial firms. Consistent with the forex competition hypothesis, changes in forex exposure coefficients of multinationals were shown to be a function of firm characteristics (e.g., the percentage of foreign sales), regional factors (e.g., geography and currency strength), and industry characteristics (e.g., competition and traded goods).

Entorf, Moebert and Sonderhof (2007) examined the foreign exchange rate exposure of 27 nations. They found that national foreign exchange rate exposure coefficients are significantly related to the current trade balances of corresponding economies. Export leaders with positive exchange rate exposures profited from currency depreciation,

2. See also studies by Barr, Breedon, and Miles (2003), Micco, Stein, and Ordóñez (2003), Tenreyro and Barro (2003), and Bun and Klaassen (2007) that have reported increased trade within EMU countries due to the euro. 
and vice versa for import-oriented nations with negative exposures. Notably, the size of the exposure coefficient for Finland was about three times that of Sweden, and both nations appeared to be export-oriented. Based on 817 multinational European firms, another study by Muller and Verschoor (2006) documented that a depreciating (appreciating) euro against foreign currencies had a net negative (positive) impact on European stock returns. While short-term exposure is hedged for the most part, forex exposure increased with longer holding periods and firm size. ${ }^{3}$ And, recent work by Bris, Koskinen and Nilsson (2009) has reported increased Tobin's Q-ratios after the introduction of the euro among 11 countries adopting the common currency. Along with Ireland, Italy, Portugal, and Spain, Finland was identified as a weak euro country due to significant currency depreciations against the German mark during the currency crisis in the early 1990s. According to the authors, these countries in particular should benefit from euro adoption in terms of monetary commitment to prevent major devaluations. Indeed, noticeably larger corporate valuation increases in euro-adopting versus non-euro countries in Europe confirmed this supposition. ${ }^{4}$

Turning to Scandinavian research, consistent with optimum currency area theory, Jonung and Sjöholm (1999) argued that countries with similar industrial structures will be affected analogously by sector-specific asymmetrical disturbances. As such, countries that are members of a currency union should exhibit the same sort of industrial structure (Mundell, 1961). The authors inferred that, if the European monetary union led to increased trade (as evidenced by some of the aforementioned studies), Sweden and Finland should participate in the EMU instead of forming an independent currency union. As documented by Jonung and Sjöholm, these two countries have strong interdependencies with respect to their industrial structures. Using an index for industrial similarity for Finland, they find that Sweden has the highest similarity of $85 \%$. The correlation between annual growth rates of Finnish and Swedish industrial production was also highest among

3. In a study of French companies, Nguyen, Faff and Marshall (2007) showed that the introduction of the euro was associated with a reduction in the number of firms with significant exchange rate exposures as well as the absolute size of exposures. Also, the use of foreign currency derivatives was associated with lower exchange rate exposure. See also Rees and Unni (2005), who investigated the pre-euro exposure to exchange rate movements of large firms in the United Kingdom, France, and Germany.

4. Bris, Koskinen, and Nilsson (2009) provide an excellent survey of literature on the financial and economic impacts of the euro on EMU countries. 
the European countries, as high as 0.79 . Due to these parallels, they cautioned that, if Finland joined the EMU but not Sweden, economic and political tensions could increase between the two countries.

Antell and Vaihekoski (2007) tested international asset pricing models (IAPT) for Finnish firms. Using data from 1970 to 2004, which encompasses the gradual liberalization of Finnish financial markets as well as several currency regimes from the gold standard to fixed and floating currency regimes ending with EMU membership, their results showed that the prices of world-market and local-market risks were time-varying. Relevant to the later analyses of exchange rate exposures of Finnish firms, currency risk was priced in the Finnish market but not time-varying.

Koutmos and Knif (2011) estimated both the first- and second-moment USD/Euro exchange rate exposure for the Finnish stock market. They provide evidence of both market-level and residual industry-level exposure in the pre-euro period. After the introduction of the euro, both exchange rate exposures became insignificant with a few exceptions. They conclude that the introduction of the euro had a profound impact on the USD/Euro exchange rate exposure for the Finnish stock market.

The present study contributes to these and previously cited papers in the introduction on the forex competition hypothesis by investigating the impact of exchange rate shocks on the competitiveness of Finnish firms vis-à-vis counterpart Swedish firms before and after the introduction of the euro. Do unexpected changes in exchange rates make some Finnish industries better (worse) off relative to the market? Did Finnish firms' exposure to exchange risk change in response to EMU membership? And, does the type of exchange rate shocks change the competitiveness of Finnish industries or sectors with corresponding Swedish counterparts? The answers to these questions are worthwhile in light of the fact that the international competitiveness of many small, export-oriented countries around the world is potentially affected by exchange rate shocks.

\section{Empirical Methodology}

Following the empirical approach of Griffin and Stulz (2001), sector and industry returns are measured in excess of market returns. Consequently, a positive return indicates that the sector or industry 
performed better than the market on average over the return horizon.

Log-returns are computed as:

$$
r_{i, t}^{K}=\ln \left(P_{i, t}^{K} / P_{i, t-1}^{K}\right),
$$

where $P_{i, t}^{K}$ represents the corresponding price indexes for country $K$ (i.e., Finland $(F I)$ and Sweden $(S W)$ ). Both price indexes are denominated in local currency. Excess returns for the $i$ th sector or industry in each country are computed as follows:

$$
\tilde{r}_{i, t}^{K}=r_{i, t}^{K}-r_{m, t}^{K}
$$

where $r_{m, t}^{K}$ is log-return on the corresponding market portfolio for country $K$. Finnish sector and industry excess returns are expressed in terms of the Finnish markka (FIM) and those for Swedish sectors and industries are expressed in Swedish krona (SEK).

Shocks to exchange rates are measured as log-returns of one currency relative to the other currency. If $X_{t}$ is the exchange rate at time $t$ in terms of the number of Swedish krona per Finnish markka, then the log-return on the currency, $r_{t}^{F X}$, is computed as:

$$
r_{t}^{F X}=\ln \left(X_{t} / X_{t-1}\right)
$$

Hence, a positive return on the exchange rate indicates that the Finnish markka has appreciated against the Swedish krona.

As a first step in the empirical analysis, a simple benchmark model is estimated, which takes into account the total market exposure with respect to the forex exposure. The study follows the traditional empirical strand of modeling the forex exposure. The approach was introduced by Adler and Dumas $(1980,1983,1984)$ and applied by Jorion (1990, 1991), Griffin and Stulz (2001), Bartram and Karolyi (2006), Bartram, Brown and Minton (2010), Koutmos and Knif (2011), and others. This means that the return on the exchange rate is considered exogenous with respect to fairly short-run stock returns as in previous literature. The estimated model is:

$$
r_{m, t}^{F I}=a_{m}+b_{m} r_{t}^{F X}+\varepsilon_{t},
$$


where the $r_{m, t}^{F I}$ is the Finnish stock market index return, and $r_{i, t}^{F X}$ is the log-return on the SEK/FIM exchange rate (i.e., the change in the exchange rate of Swedish krona to one Finnish markka). Equation (4a) estimates the average impact of exchange rate movements on Finnish stock returns under the assumption that they are contemporaneously incorporated into stock prices. Furthermore, to control for global market integration in the equation (4a) the benchmark model is extended as:

$$
r_{m, t}^{F I}=a_{m}+b_{m} r_{t}^{F X}+g_{m} r_{t}^{W I}+\varepsilon_{t},
$$

where the regression coefficient $b_{m}$ reflects the total market exposure (i.e., sensitivity) to changes in the exchange rate, and the coefficient $g_{m}$ measures and controls for the impact of global market integration with respect to log-returns on the MSCI world index of stocks, $r_{t}^{W I}$. In this regard, it is assumed that the return on the world market index is exogenous with respect to the Finnish market return.

Additionally, to account for sector or industry residual or excess exposure over the market, the study utilizes excess returns, or $\tilde{r}_{i, t}^{F I}=r_{i, t}^{F I}-r_{m, t}^{F I}$, and estimates the following model:

$$
\tilde{r}_{i, t}^{F I}=a_{i}+b_{i} r_{t}^{F X}+g_{i} r_{t}^{W I}+\varepsilon_{i, t}
$$

For individual sectors, a significant positive (negative) coefficient would suggest that an increase in the SEK/FIM exchange rate is more (less) beneficial for this sector than for the market as a whole. A coefficient close to zero would indicate that this sector is affected by the exchange rate shock in about the same way as the market. Significant exposure sensitivity in equations (4a) to (4c) is week evidence in favor of the forex competition hypothesis.

Like Griffin and Stulz, in order to more explicitly test the forex competition hypothesis, the following extended model for Finnish sectors and industries is estimated:

$$
\tilde{r}_{i, t}^{F I}=a_{i}+b_{i} r_{t}^{F X}+d_{i} \tilde{r}_{i, t}^{S W}+g_{i} r_{t}^{W I}+\varepsilon_{i, t}
$$

In this equation, the excess return of the $i$ th Swedish sector or industry over the Swedish market return, $\tilde{r}_{i, t}^{S W}$, is added as an explanatory variable. In this case, the applied univariate approach regards Swedish 
excess returns as exogenous due to the fact that previous empirical research indicates that Finnish stock returns do not directly affect Swedish stock returns. Knif, Pynnönen and Luoma (1995) show that the Swedish market leads the Finnish market, while Pynnönen and Knif (1998) find no Granger causality between the returns on the Finnish and Swedish stock markets. Knif and Pynnönen (2001) report a cointegration relationship between the Swedish and Norwegian markets that affects the Finnish market but no effect from Finland to the Swedish market. They further find evidence of a spillover effect in return and volatility that runs from Sweden to Finland.

Note also that the world market return is used in the models as a control variable to monitor the state of the general global economy and is regarded as exogenous when modeling the return on the small Finnish industry and market returns. On the other hand, the Swedish industry excess returns are specifically used for testing the competitiveness hypothesis and do not measure a market effect.

In equation (5) the estimated coefficient $d_{i}$ measures the relation between market excess returns for the sector or industry of the two countries. A significant negative coefficient would be indicative of cross-border competitiveness between sectors or industries. That is, competitiveness implies that Finnish sector or industry returns (in excess of Finnish market returns) decrease when counterpart Swedish sector or industry returns (in excess of Swedish market returns) increase, and vice versa. If Finnish firms' returns move in the same direction as matched Swedish firms' returns over time (i.e., a positive $d_{i}$ coefficient), competitiveness is not supported; instead, market integration is implied.

It is possible that the co-movement between Finnish and Swedish sector or industry stock returns is affected by exchange rate shocks or the size of the shock. To test this extended forex competition hypothesis, as in Griffin and Stulz, the model is augmented with interaction variables. This interaction component allows for dependencies between exchange rate movements and relative sector or industry competition (or market integration) between the two countries. The full extended model including the interaction variables is: ${ }^{5}$

5. As in Griffin and Stulz (2001, footnote 23), we model the variances of the regression residuals in equations (4) to (6). An $\operatorname{EGARCH}(1,1)$ process is used for this purpose, which takes into account autocorrelation, heteroscedasticity, and asymmetry in volatility. 


$$
\begin{aligned}
\tilde{r}_{i, t}^{F I}= & a_{i}+b_{i} r_{t}^{F X}+c_{i}\left|r_{t}^{F X}\right|+d_{i} \tilde{r}_{i, t}^{S W} \\
& +g_{i} r_{t}^{W I}+e_{i} r_{t}^{F X} \tilde{r}_{i, t}^{S W}+f_{i}\left|r_{t}^{F X}\right| \tilde{r}_{i, t}^{S W}+\varepsilon_{i, t} .
\end{aligned}
$$

The inclusion of the absolute exchange return makes it possible to model a positive-negative asymmetry effect due to forex shocks. Note that the absolute value of exchange rate shocks also can be interpreted as a proxy for forex volatility. In this way co-movements between sector or industry stock returns can be examined conditional on the characteristics of exchange rate shocks.

\section{Data}

The data consists of three different sets of weekly returns: (1) stock market total return indexes (TRI) ${ }^{6}$ for individual firms in Finland and Sweden, (2) aggregate stock market total index returns for the MSCI World Index as well as for Finland and Sweden (i.e., the OMX Helsinki Cap index denoted OMXH CAP ${ }^{7}$ and the OMX Stockholm index denoted $\mathrm{OMXS}^{8}$, respectively), and (3) exchange rate series for the Finnish (FIM) and Swedish (SEK) currencies expressed in U.S. dollars (USD). For comparison reasons, the FIM notation is used for the entire

6. The total return index (TRI) data is used because it takes into account the time-varying adjustment of dividends for all available companies in both Finland and Sweden. However, in some cases, due to the unavailability of TRI series, the company closing price index was used.

7. The Finnish OMXH CAP index is based on all listed shares on the Helsinki Stock Exchange. Unlike the Finnish OMXH index, market values of constituent firms are capped at a maximum of $10 \%$ of the total market value of the index. If one company's share dominates due to large weights in the index (e.g., Nokia accounted for $70 \%$ of the total market value of HEX in the last quarter of 2000), it is likely to over-represent that particular sector or industry and skew the index performance. Hence, OMXH CAP better reflects the general performance of the Finnish stock market than the OMXH. Furthermore, the Finnish and Swedish stock market, which is known as NASDAQ OMX Group as on May 25, 2007 NASDAQ agreed to buy the Swedish-Finnish financial company OMX. The final deal was completed on February 27, 2008. However, in our study, Finnish stock market has been referred as OMXH and OMXH CAP and Swedish market is referred as OMXS.

8. For Sweden, the series Sweden-DS total return index is selected, which is calculated by Datastream to reflect the total value-weighted return of the Swedish stock market. No other market portfolio series are available for the selected time period. 
sample period. For the post-euro period, the fixed exchange rate of 5.94573 FIM for 1 euro is used for currency conversion. An obvious alternative would have been to use the euro instead with the fixed rate against the markka for the pre-euro period.

Global Industrial Classification Standard (GICS) codes are employed to classify sectors and industries. ${ }^{9}$ Sector and industry-group classifications are used due to data availability gaps for the two less aggregated classifications. Alternatively, a firm-level analysis could be conducted, but this level of detail is beyond the scope of the present paper. Furthermore, the study utilizes a weekly return horizon. Monthly and quarterly data could have been used, but this would reduce the sample size, especially in the pre-euro period. Data was available for the following six sectors: materials, industrials, consumer discretionary, consumer staples, financials, and information technology. Within each sector, industry groups are selected using level 2 GICS codes. Firms' market capitalizations are used to compute weighted log-returns for different sector and industry portfolios. ${ }^{10}$ While most sectors and industries are export oriented, the consumer staples, consumer discretionary, and financials sectors in both countries appear to be primarily domestic in nature.

The sample period is determined by the availability of comparable data for sector and industry classification in the period January 1, 1994 to June 1, 2009. ${ }^{11}$ To take into account the introduction of the euro on January 1, 1999, the sample period is divided into pre- and post-euro series (i.e., January 1, 1994 to Dec 31, 1998 and January 1, 1999 to June 1,2009 , respectively). The final samples of companies contain 71 firms in Finland and 87 firms in Sweden.

Descriptive statistics are shown in table 1 for market index returns, sector excess returns, and exchange rate variables for Finland and Sweden in the pre- and post-euro sample periods. Kurtosis and

9. GICS codes were developed by MSCI and Standard \& Poor's in 1999 to provide a reliable, complete, and standard industry classification system for global sectors and industries. They are currently used in the OMXH and OMXH CAP (Helsinki Stock Exchange) as well as the OMXS (Stockholm Stock Exchange).

10. Weights are calculated with respect to listed companies' share values, or market capitalizations, in both the Finnish (OMXH CAP) and Swedish (OMXS) market indexes. Market capitalization is measured annually from 1994 to 2009, and median values are used to compute the weights for each sector and industry.

11. Data are obtained from various sources, including Thomson Financials, Datastream, and the Pacific Exchange Rate Service. 


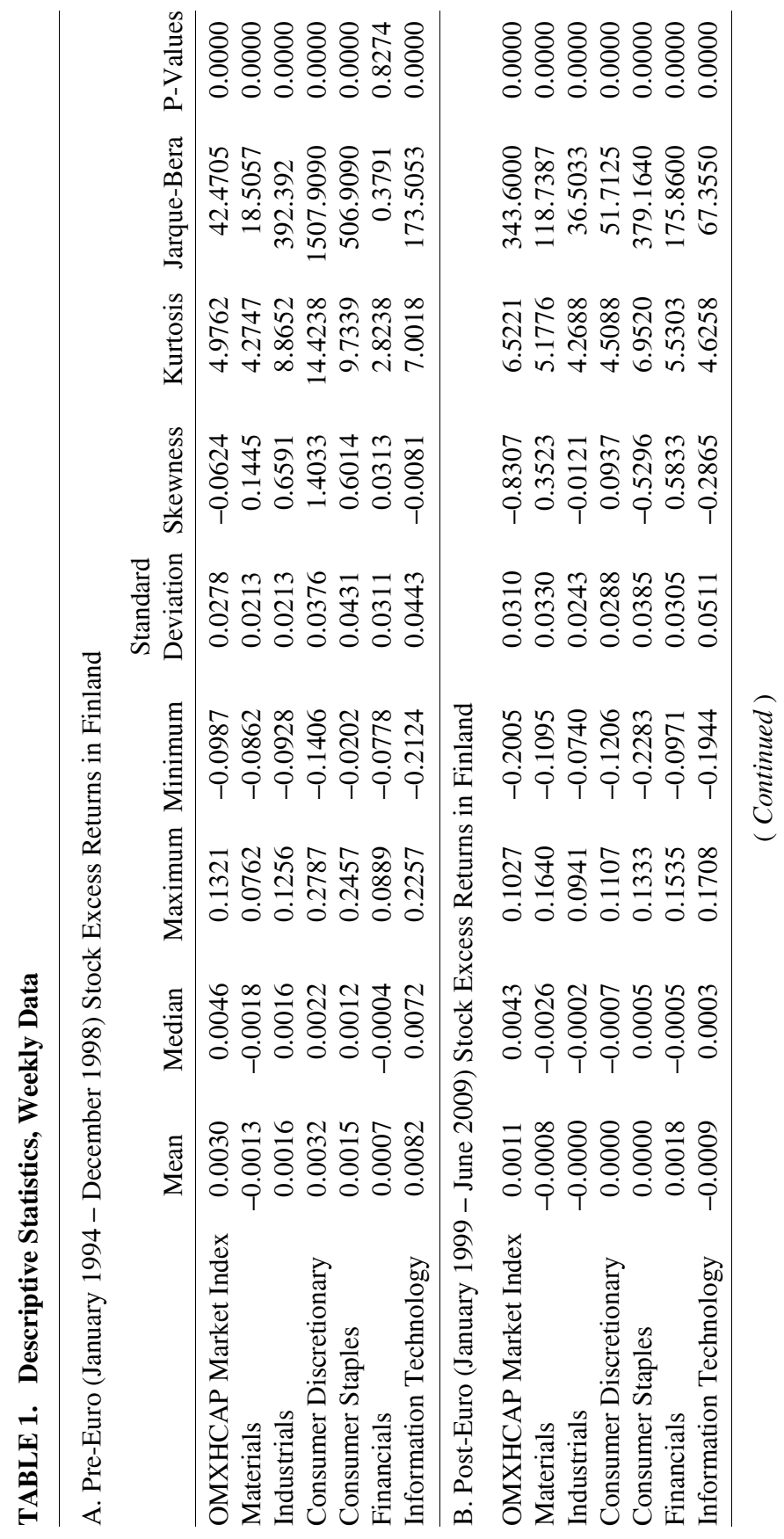




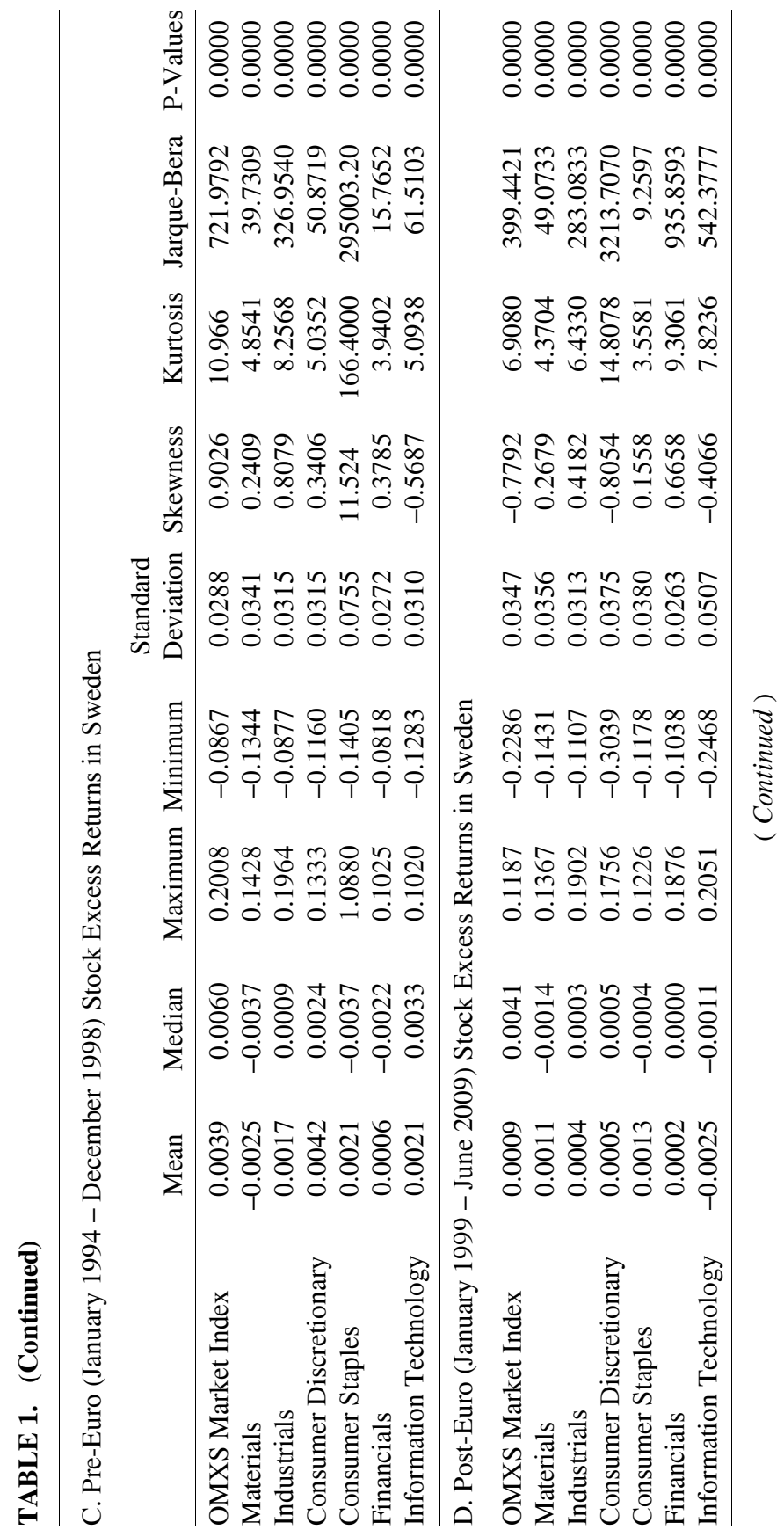




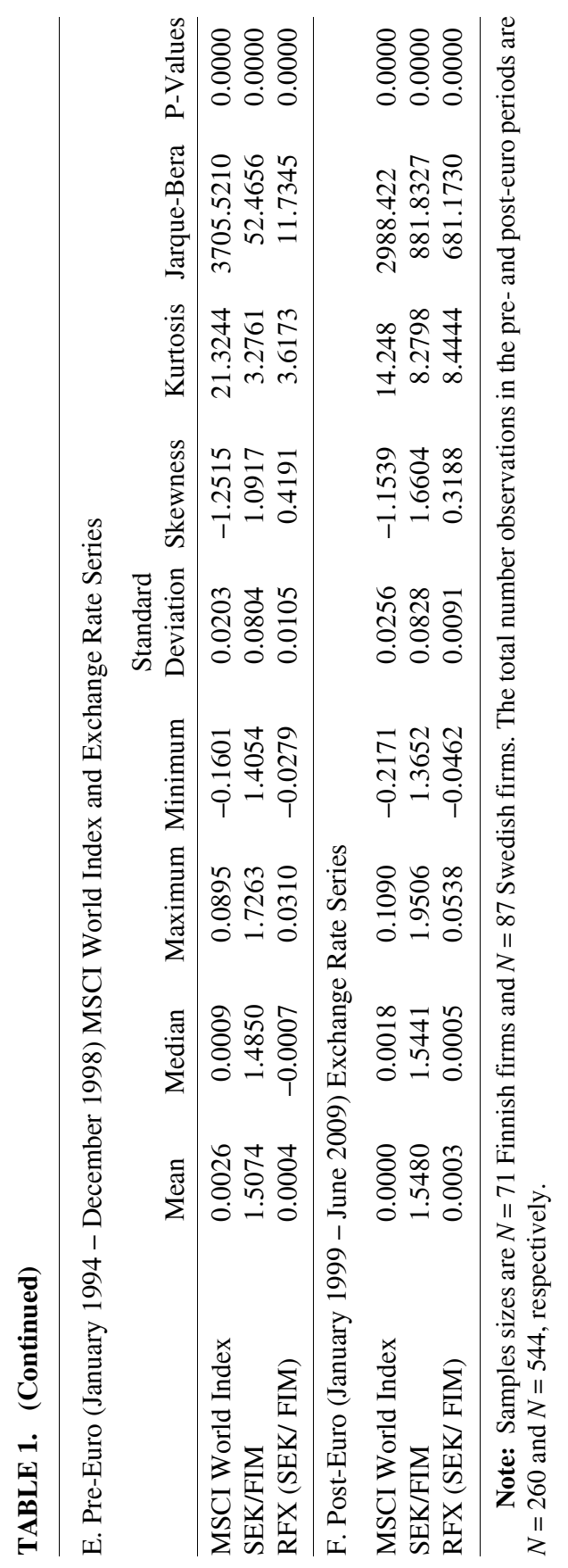


Jarque-Bera values indicate fat tails and non-normality for the return distributions, except for the Finnish financial sector in the pre-euro period (i.e., the kurtosis is less than 3.0). For Finnish stocks, kurtosis of the OMXHCAP increased in the post-euro period. However, the OMXS kurtosis for Swedish stocks decreased from 10.96 to 6.90, and the MSCI world index kurtosis decreased from 21.32 to 14.25. Likewise, in the post-euro period, skewness increased for the MSCI world index but decreased for the OMXS and the OMX CAP. Also, the OMXS series was positively skewed before the euro but became negatively skewed in the post-euro period.

\section{Empirical Analyses}

In the first step of the empirical analysis, the sensitivity of the Finnish equity market to exchange rate shocks is estimated using the simple regression in equation (4a) with the log-return on the Finnish market index series OMXH CAP, $r_{m, t}^{F I}$, as the dependent variable and the log-return on the SEK/FIM exchange rate, $r_{t}^{F X}$, as the explanatory variable. The results for the pre- and post-euro sample periods are presented in table 2.

As shown in table 2, the estimated exposure coefficients $(\hat{b})$ are significant at the $1 \%$ level with negative signs in both sample periods. Confirming at least weak support for the forex competition hypothesis, depreciation of the FIM against the SEK positively affected Finnish stock market returns. This positive benefit of currency depreciation is more pronounced in the post-euro period, as the estimated coefficient almost doubled in magnitude with coincidently higher $z$-statistic and adjusted $R^{2}$ values. However, controlling for global market integration via equation (4b), shows that there exists a highly significant positive relation between the OMXH CAP and MSCI world market indices. The magnitude of the world market exposure more than doubled in the post-euro period vis-à-vis pre-euro period. As expected, the adjusted $R^{2}$ values significantly increased from 0.099 in pre-euro to 0.515 in post-euro period with the inclusion of MSCI world market index in the equation. Apparently, Finnish stocks are still more sensitive to euro movements compared with Finnish markka fluctuations in earlier years. One plausible reason for this change is gradually increasing export activity of firms in Finland over time. Another possible explanation is that, given the euro is exogenous and not subject to central bank 
TABLE 2. Finnish Market Index Returns Regressed on Exchange Rate Shocks and MSCI World Index, Weekly Data

\begin{tabular}{lcllc} 
A. Pre-Euro (January $1994-$ December 1998) & \multicolumn{1}{c}{$\hat{b}$} & $\hat{g}$ & Adjusted $R^{2}$ \\
\hline OMXH CAP & $0.0036^{* * *}$ & $-0.5284 * * *$ & & \\
& $(2.30)$ & $(-3.50)$ & & 0.0383 \\
OMXH CAP & 0.0023 & $-0.4758^{* * * *}$ & $0.3677 * * *$ & \\
(with MSCI World Index) & $(1.60)$ & $(-3.34)$ & $(6.22)$ & 0.0997 \\
\hline B. Post-Euro (January 1999 - June 2009) & & & \\
OMXH CAP & $0.0033^{* * *}$ & $-0.9828^{* * *}$ & & \\
& $(3.07)$ & $(-6.84)$ & & 0.1178 \\
OMXH CAP & 0.0017 & $-0.3120^{* * *}$ & $0.9110^{* * * *}$ & \\
(with MSCI World Index) & $(2.33)$ & $(-3.57)$ & $(30.80)$ & 0.5147
\end{tabular}

Note: Asterisks ***,**, and $*$ denote $1 \%, 5 \%$, and $10 \%$ significance levels, respectively (z-statistics in parenthesis). The total number observations in the pre- and post-euro periods are $N=260$ and $N=544$, respectively. The estimated models are: $r_{O M X H C A P, t}^{F I}=a_{m}+b_{m} r_{t}^{F X}+\varepsilon_{t}$, and $r_{O M X H C A P, t}^{F I}=a_{m}+b_{m} r_{t}^{F X}+g_{m} r_{t}^{W I}+\varepsilon_{t}$, where $r_{O M X H C A P, t}^{F I}$ is the log-return on the Finnish stock market index, $r_{t}^{W I}$ is the log-return on the MSCI world index, and $r_{t}^{F X}$ is the log-return on the SEK/FIM exchange rate (i.e., the change in the exchange rate in terms of Swedish krona to one Finnish markka or euro). EGARCH $(1,1)$ process coefficients are significant for both pre-and post-euro period, which indicates that autocorrelation, heteroskedasticity, and asymmetry in the volatility of the error term are taken into account.

intervention to devalue and promote exports, Finnish firms may have become more sensitive to exchange rate movements than in the pre-euro period.

The results of estimating equation (4c) for the six sectors in the two sample periods are shown in table 3 . The dependent variable is now the Finnish excess return $\left(\tilde{r}_{i, t}^{F I}\right)$ of the sector over the market return. During the pre-euro period in Panel A, the estimated residual forex exposure coefficients $(\hat{b})$ for industrials, consumer discretionary and financial are significant. Hence, in the pre-euro period, it appears that the market portfolio captures most of stocks' exchange rate exposure, but there is some residual exposure in selected sectors that reflects idiosyncratic differences from the negative market exposure. However, since the adjusted $R^{2}$ values are almost zero, it is inferred that the overall market in fact captures the majority of stocks' average exchange rate exposure.

In the post-euro period in Panel B, the results are different in most respects with some similarities. The estimated residual forex exposure 
TABLE 3. Finnish Sector Excess Returns Regressed on Exchange Rate Shocks, Weekly Data

\begin{tabular}{|c|c|c|c|c|}
\hline \\
\hline \multicolumn{5}{|c|}{$\begin{array}{l}\text { A. Pre-Euro (January } 1994 \text { - December 1998) } \\
\text { Sectors }\end{array}$} \\
\hline Materials & -0.0014 & -0.2260 & -0.0180 & -0.0124 \\
\hline Industrials & $\begin{array}{l}0.0013 \\
(0.90)\end{array}$ & $\begin{array}{l}0.3504 * * \\
(2.64)\end{array}$ & $\begin{array}{l}-0.0440 \\
(-0.72)\end{array}$ & -0.0123 \\
\hline Consumer Discretionary & $\begin{array}{l}0.0016 \\
(0.74)\end{array}$ & $\begin{array}{l}0.5621^{* * *} \\
(3.22)\end{array}$ & $\begin{array}{l}-0.1053 \\
(-1.01)\end{array}$ & -0.0016 \\
\hline Consumer Staples & $\begin{array}{l}0.0014 \\
(0.61)\end{array}$ & $\begin{array}{l}-0.0885 \\
(-0.36)\end{array}$ & $\begin{array}{l}0.0453 \\
(0.64)\end{array}$ & -0.0276 \\
\hline Financials & $\begin{array}{l}0.0025 \\
(1.35)\end{array}$ & $\begin{array}{l}-0.4155^{* *} \\
(-2.30)\end{array}$ & $\begin{array}{l}0.0992 \\
(1.31)\end{array}$ & -0.0065 \\
\hline Information Technology & $\begin{array}{l}0.0081 \text { *** } \\
(3.31)\end{array}$ & $\begin{array}{l}0.2052 \\
(0.75)\end{array}$ & $\begin{array}{l}0.0798 \\
(0.58)\end{array}$ & -0.0241 \\
\hline \multicolumn{5}{|c|}{ B. Post-Euro (January 1999 - June 2009) } \\
\hline Materials & $\begin{array}{l}-0.0020 \\
(-1.61)\end{array}$ & $\begin{array}{l}-0.0383 \\
(-0.30)\end{array}$ & $\begin{array}{l}0.1404 * * * \\
(2.71)\end{array}$ & 0.0142 \\
\hline Industrials & $\begin{array}{l}0.0000 \\
(0.03)\end{array}$ & $\begin{array}{l}0.2413 * * \\
(2.30)\end{array}$ & $\begin{array}{l}-0.3256^{* * * *} \\
(-9.55)\end{array}$ & 0.1624 \\
\hline Consumer Discretionary & $\begin{array}{l}-0.0003 \\
(-0.30)\end{array}$ & $\begin{array}{l}-0.0146 \\
(-0.11)\end{array}$ & $\begin{array}{l}-0.2861 * * * \\
(-7.07)\end{array}$ & 0.0425 \\
\hline Consumer Staples & $\begin{array}{l}0.0024 * \\
(1.90)\end{array}$ & $\begin{array}{l}-0.0610 \\
(-0.40)\end{array}$ & $\begin{array}{l}-0.4824 * * * \\
(-8.70)\end{array}$ & 0.0613 \\
\hline Financials & $\begin{array}{l}0.0013 \\
(1.31)\end{array}$ & $\begin{array}{l}0.1743 \\
(1.30)\end{array}$ & $\begin{array}{l}-0.0806^{*} \\
(-1.70)\end{array}$ & -0.0072 \\
\hline Information Technology & $\begin{array}{l}-0.0017 \\
(-0.80)\end{array}$ & $\begin{array}{l}-0.2760 \\
(-1.40)\end{array}$ & $\begin{array}{l}0.3710^{* * * *} \\
(5.81)\end{array}$ & 0.0153 \\
\hline
\end{tabular}

Note: Asterisks ***,**, and $*$ denote $1 \%, 5 \%$, and $10 \%$ significance levels, respectively ( $z$-statistics in parenthesis). There are $N=71$ Finnish firms and $N=87$ Swedish firms. The total number observations in the pre- and post-euro periods are $N=260$ and $N=544$, respectively. The estimated model is: $\tilde{r}_{i, t}^{F I}=a_{i}+b_{i} r_{t}^{F X}+g_{i} r_{t}^{W I}+\varepsilon_{i, t}$, where $\tilde{r}_{i, t}^{F I}$ is the Finnish sector return in excess of the Finnish stock market return, $r_{t}^{F X}$ is the log-return on the SEK/FIM exchange rate (i.e., the change in the exchange rate in terms of Swedish krona to one Finnish markka or euro), and $r_{t}^{W I}$ is the log-return on the MSCI world index of stocks. EGARCH $(1,1)$ process coefficients are significant for both pre-and post-euro period, which indicates that autocorrelation, heteroskedasticity, and asymmetry in the volatility of the error term are taken into account.

coefficients $(\hat{b})$ are now significant only for the industrial sector. While the consumer discretionary and financial sectors in the pre-euro period 
are significant, no significant exposure is found in the post-euro period for these sectors. Also, the information technology and consumer discretionary sectors changed from no exposure in the pre-euro period to more negative exposure than the market in the post-euro period, albeit not statistically significant. Financials changed from significant negative in the pre-euro period to insignificant positive excess market exposure in the post-euro period. And, industrials had significant positive exposure in both periods. Focusing on the post-euro period, the results generally indicate that an appreciating euro against the Swedish krona negatively affected Finnish stocks. However, the world index becomes more statistically significant for all sectors in the post-euro period, whereas in pre-euro period it was not significant for any sectors. As expected, some Finnish sectors seem to be less sensitive to changes in the world market than the market on average, as four-out-of-six estimated global index coefficients $(\hat{g})$ are negative and statistically significant.

In order to test sector competitiveness (market integration), equation (5) is estimated in the pre- and post-euro periods. The estimated exposure coefficient $(\hat{b})$ results in table 4 are similar to those for equation (4c) in table 3 . As before, there is some significant evidence of residual exposure in the pre- and post-euro periods in selected sectors. More importantly, consistent with results in Griffin and Stulz, the predominance of significant positive estimated coefficients on Swedish excess sector returns $(\hat{d})$ supports market integration over competitiveness between sectors in the two countries. Also, in the pre-euro period, with the exception of the consumer discretionary and financial sector, all Swedish sectors' estimated coefficients are significant at the $10 \%$ level or lower. In the post-euro period, all Swedish sectors' estimated coefficients $(\hat{d})$ are highly significant and normally larger in magnitude (except for information technology sector) than in the pre-euro period. These results imply a higher level of cross-border co-movements between sectors in the post-euro period, which suggests increasing market integration in recent years in line with earlier cited results by Jonung and Sjöholm (1999). However, for the information technology sector, the post-euro estimated $\hat{d}$ coefficients and adjusted $R^{2}$ values are reduced by about one-half of their values in the pre-euro period. Hence, this sector experienced less cross-border co-movement after the introduction of the euro. On the other hand, in the pre-euro period the world market index's estimated coefficients $(\hat{g})$ are not significant for all the sectors; however, in the post-euro period 
TABLE 4. Finnish Sector Excess Returns Regressed on Exchange Rate Shocks and Swedish Sector Excess Returns

\begin{tabular}{|c|c|c|c|c|c|}
\hline \multicolumn{6}{|c|}{ A. Pre-Euro (January 1994 - 31 December 1998) } \\
\hline Sectors & $\hat{a}$ & $\hat{b}$ & $\hat{d}$ & $\hat{g}$ & Adjusted $R^{2}$ \\
\hline \multirow[t]{2}{*}{ Materials } & -0.0006 & $-0.3323 * *$ & $0.2602 * * *$ & -0.0330 & 0.1608 \\
\hline & $(-0.52)$ & $(-2.50)$ & $(8.51)$ & $(-0.54)$ & \\
\hline \multirow[t]{2}{*}{ Industrials } & 0.0012 & $0.4001 * * *$ & 0.0720 & -0.0063 & -0.0025 \\
\hline & $(0.81)$ & $(2.93)$ & $(1.71)^{*}$ & $(-0.10)$ & \\
\hline \multirow[t]{2}{*}{ Consumer Discretionary } & 0.0016 & $0.5611 * * *$ & -0.0030 & -0.1075 & -0.0061 \\
\hline & $(0.71)$ & $(3.21)$ & $(-0.05)$ & $(-1.03)$ & \\
\hline \multirow[t]{2}{*}{ Consumer Staples } & 0.0008 & -0.0361 & $0.1532 * *$ & 0.0383 & 0.0514 \\
\hline & $(0.35)$ & $(-0.14)$ & $(2.30)$ & $(0.60)$ & \\
\hline \multirow[t]{2}{*}{ Financials } & 0.0024 & $-0.3510^{*}$ & 0.1024 & 0.1225 & 0.0013 \\
\hline & $(1.23)$ & $(-1.80)$ & $(1.61)$ & $(1.60)$ & \\
\hline \multirow[t]{2}{*}{ Information Technology } & $0.0081 * * *$ & 0.1550 & $0.4522 * * *$ & -0.0462 & 0.1280 \\
\hline & $(3.25)$ & $(0.60)$ & $(5.10)$ & $(-0.40)$ & \\
\hline \multicolumn{6}{|c|}{ B. Post-Euro (January 1999 - June 2009) } \\
\hline \multirow[t]{2}{*}{ Materials } & $-0.0020 *$ & -0.0878 & $0.3805 * * *$ & $0.2160 *$ & 0.2760 \\
\hline & $(-1.92)$ & $(-0.63)$ & $(16.00)$ & $(5.25)$ & \\
\hline \multirow[t]{2}{*}{ Industrials } & -0.0002 & $0.2362 * *$ & $0.0504 *$ & $-0.3141 *$ & $* 0.1682$ \\
\hline & $(-0.23)$ & $(2.16)$ & $(1.84)$ & $(-8.90)$ & \\
\hline \multirow[t]{2}{*}{ Consumer Discretionary } & -0.0003 & -0.0134 & $0.0526 *$ & $-0.2744 *$ & $* 0.0478$ \\
\hline & $(-0.30)$ & $(-0.10)$ & $(1.65)$ & $(-7.00)$ & \\
\hline \multirow[t]{2}{*}{ Consumer Staples } & $0.0023^{*}$ & -0.0346 & $0.1732 * * *$ & $-0.3281 *$ & $* * 0.0905$ \\
\hline & $(1.80)$ & $(-0.21)$ & $(4.61)$ & $(-5.12)$ & \\
\hline \multirow[t]{2}{*}{ Financials } & $0.0021 *$ & 0.1774 & $0.2506 * * *$ & -0.0631 & 0.0873 \\
\hline & $(1.72)$ & $(1.33)$ & $(6.40)$ & $(-1.45)$ & \\
\hline \multirow[t]{2}{*}{ Information Technology } & -0.0015 & -0.2350 & $0.2095 * * *$ & $0.3310^{*}$ & $* * 0.0620$ \\
\hline & $(-0.74)$ & $(-1.20)$ & $(7.50)$ & $(5.40)$ & \\
\hline
\end{tabular}

Note: Asterisks ***,**, and $*$ denote $1 \%, 5 \%$, and $10 \%$ significance levels, respectively ( $z$-statistics in parenthesis). There are $N=71$ Finnish firms and $N=87$ Swedish firms. The total number observations in the pre- and post-euro periods are $N=260$ and $N=544$, respectively. The estimated model is: $\tilde{r}_{i, t}^{F I}=a_{i}+b_{i} r_{t}^{F X}+d_{i} \tilde{r}_{i, t}^{S W}+g_{i} r_{t}^{W I}+\varepsilon_{i, t}$, where $\tilde{r}_{i, t}^{F I}$ is the Finnish sector return in excess of the Finnish stock market return, $r_{t}^{F X}$ is the log-return on the SEK/FIM exchange rate (i.e., the change in the exchange rate in terms of Swedish krona to one Finnish markka or euro), $\widetilde{r}_{i, t}^{S W}$ is the corresponding Swedish sector return in excess of the Swedish stock market return, and $r_{t}^{W I}$ is the log-return on the MSCI world index of stocks. EGARCH $(1,1)$ process coefficients are significant for both pre-and post-euro period, which indicates that autocorrelation, heteroskedasticity, and asymmetry in the volatility of the error term are taken into account. 


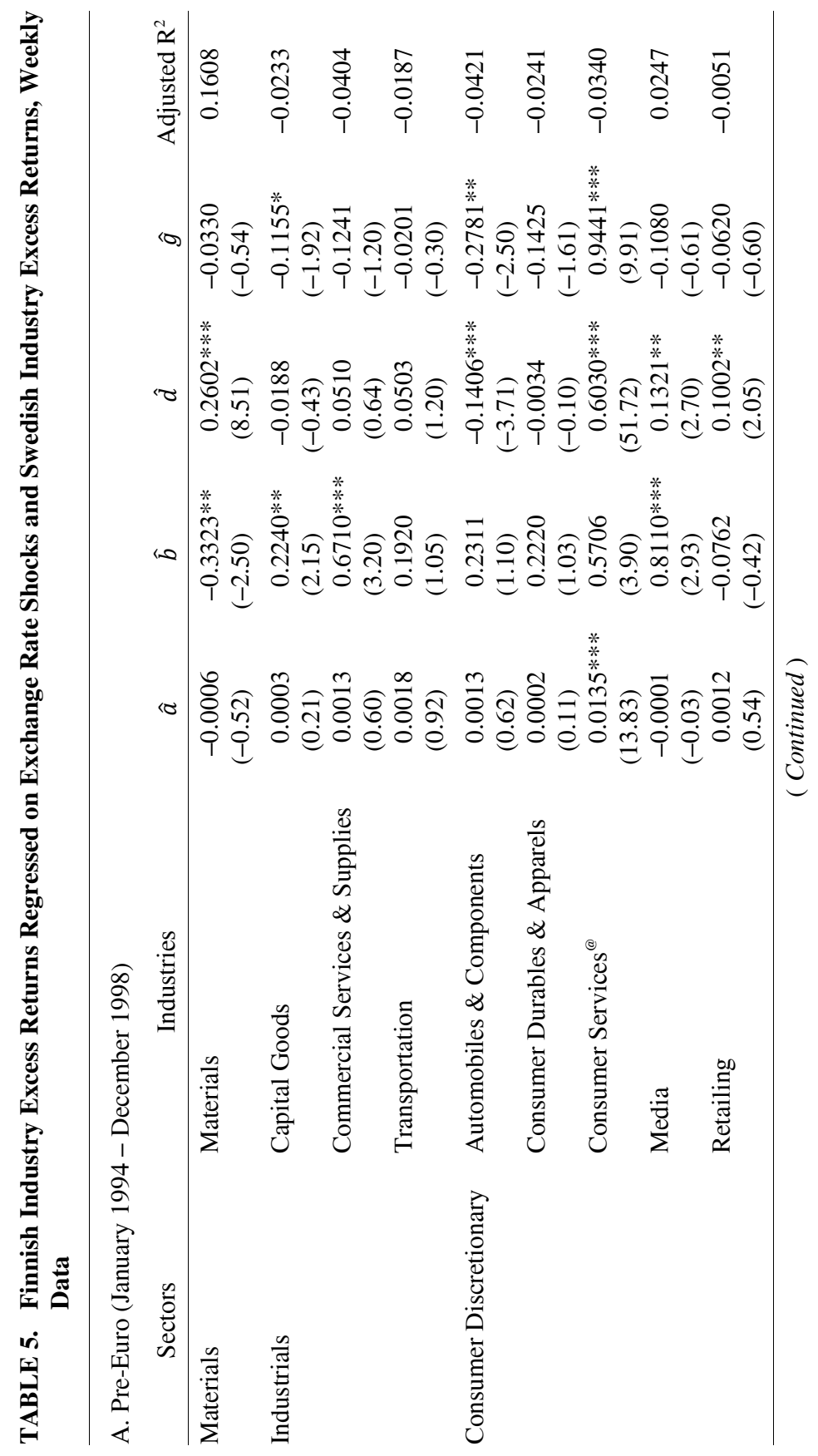




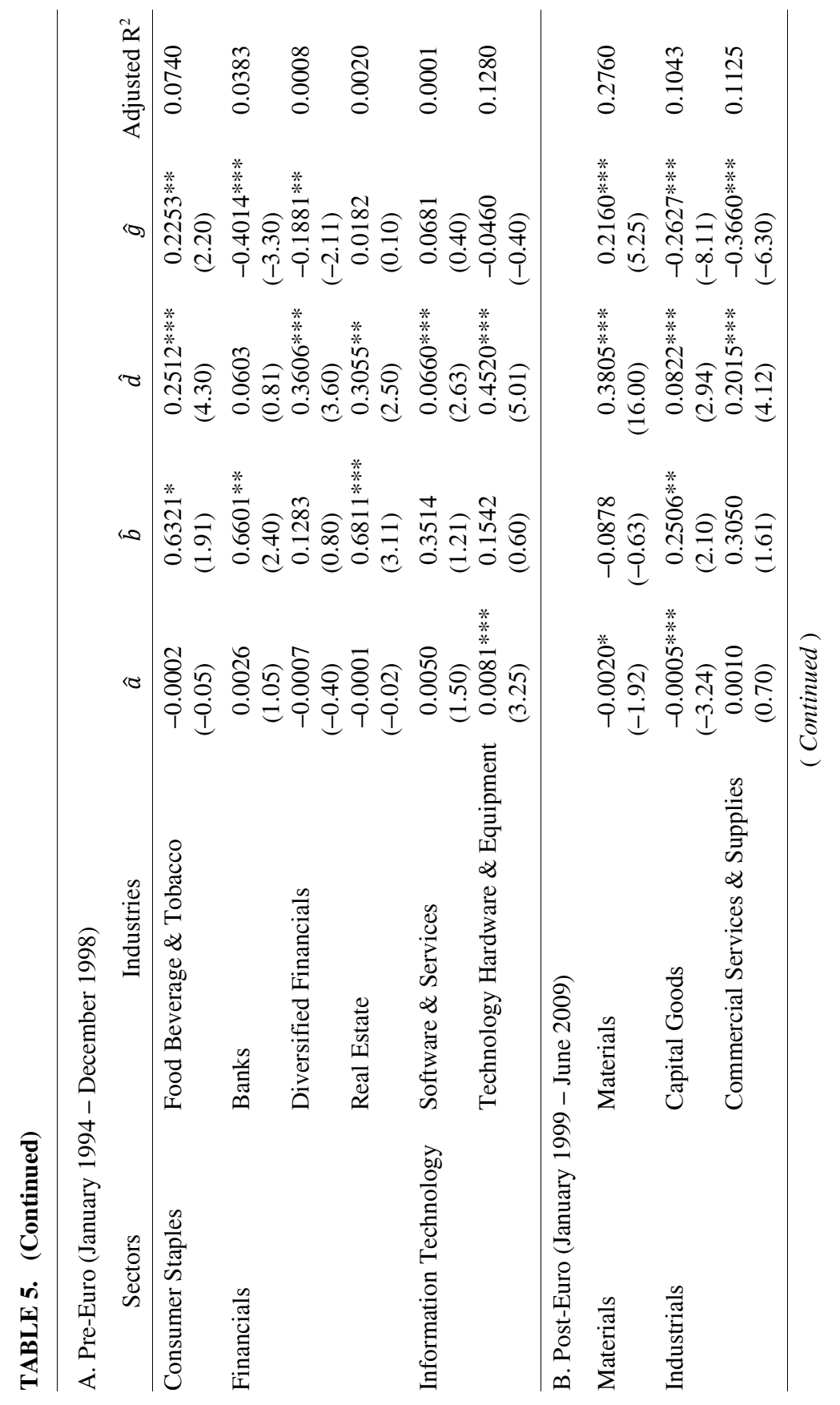




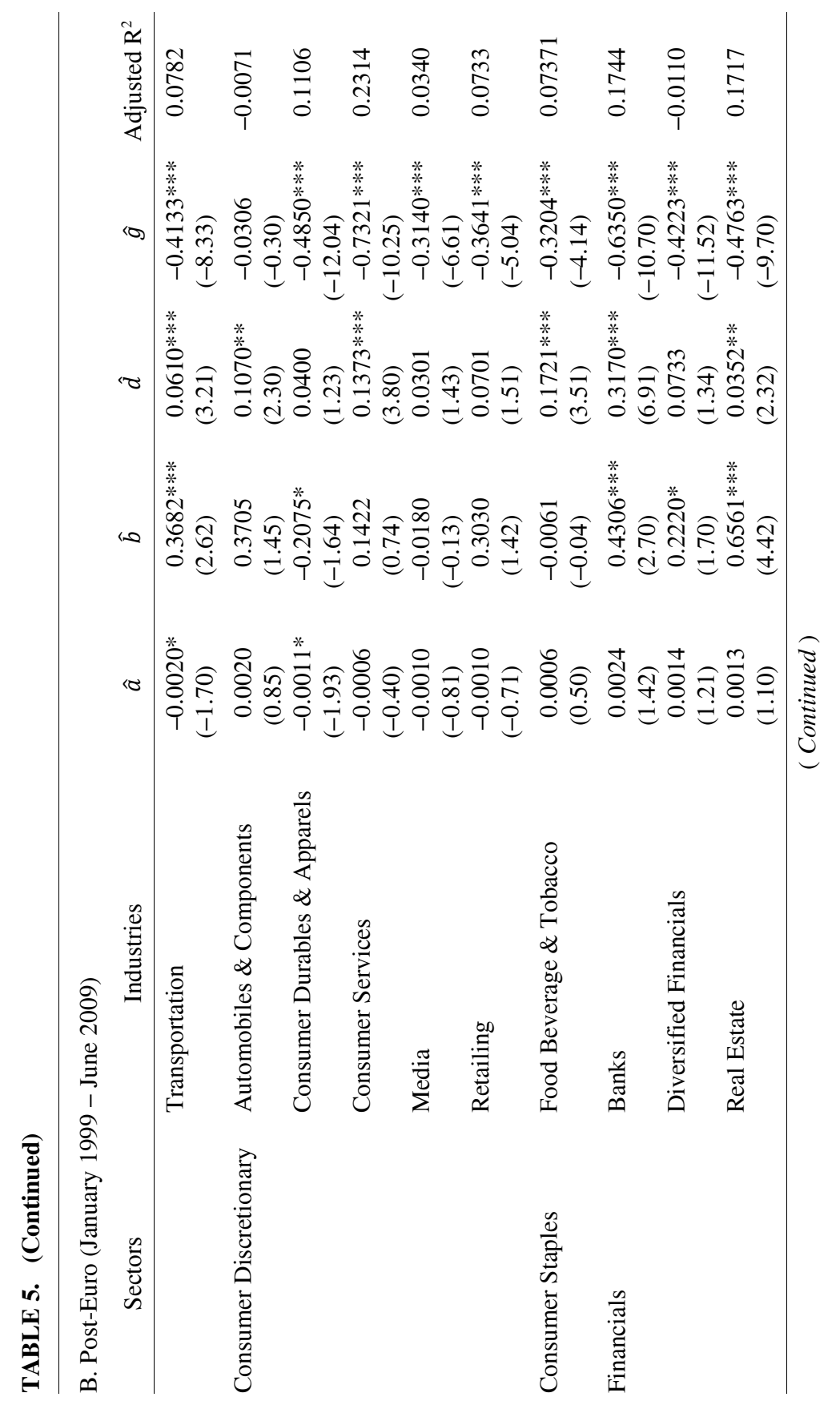




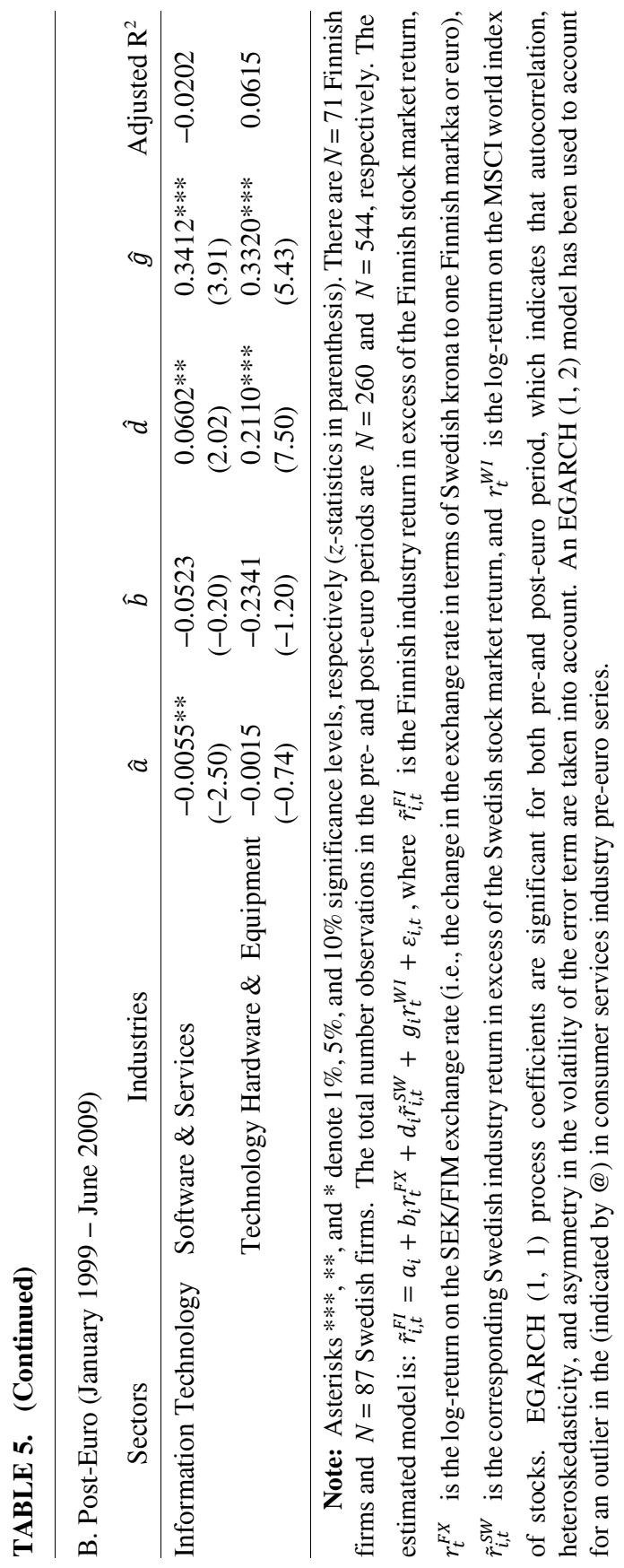




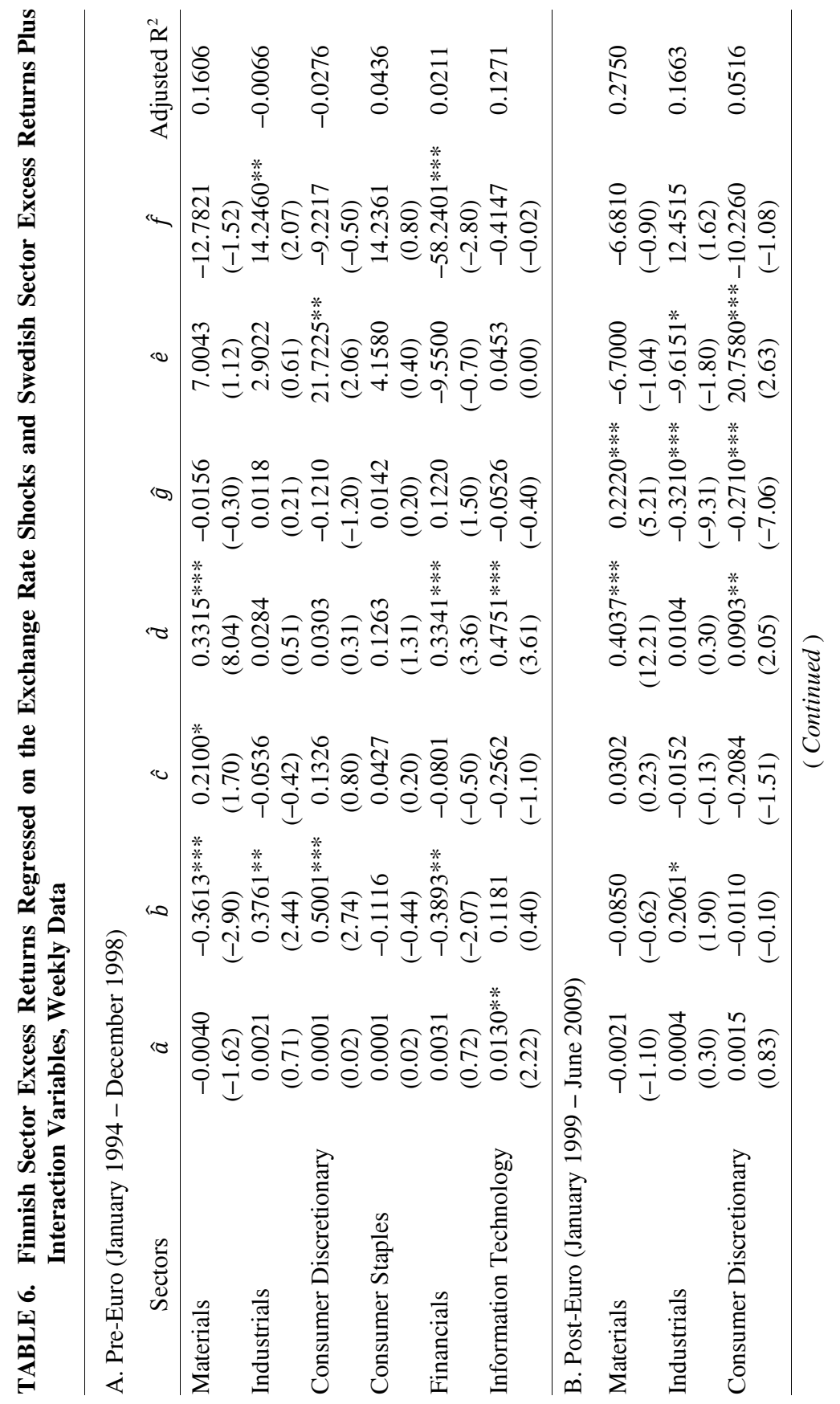




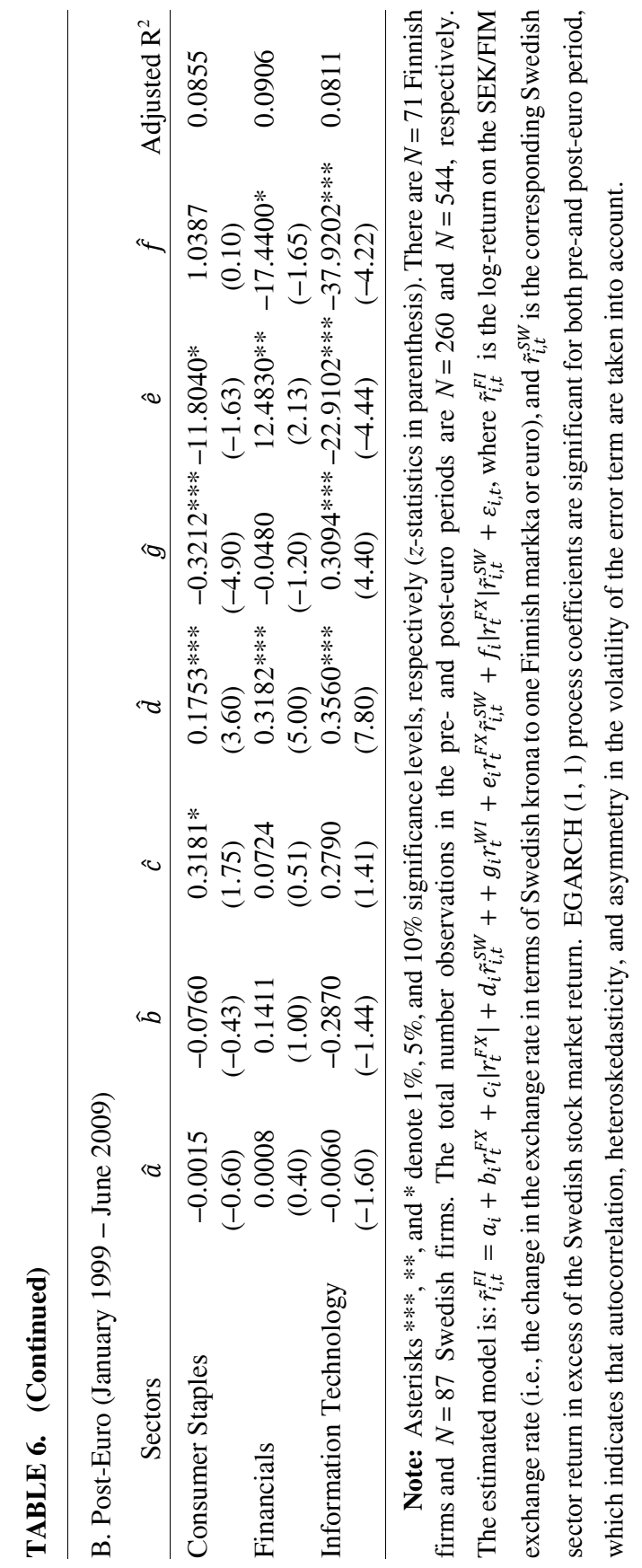


they all become highly significant at the $1 \%$ level (except for the financial sector). Furthermore, there are 4-out-of-6 negative coefficients, with three of these statistically significant. This again indicates that in the pre-euro period the market index on average covered most of the world market sensitivity, whereas in the post- euro period there is significant residual world market sensitivity at the individual sector level.

Less aggregated industry group results are provided in table 5. Similar to the sector results in table 4 , seven industry groups exhibit significant (and normally positive) excess exchange rate exposure $(\hat{b})$ in the pre-euro period compared with 6 industries (out-of-15 total) in the post-euro period. In the post-euro period, all significant exposure coefficients are positive in sign ${ }^{12}$, with the exception of the consumer durables \& apparels industry. Hence, most firms' stock valuations benefited from euro depreciation but less than the overall market.

Turning to the cross-border industry effects, with the exception of automobiles and components ${ }^{13}$, the estimated coefficients $(\hat{d})$ are significantly positive, which implies market integration between Finnish industries and their Swedish counterparts in both pre- and post-euro periods. In the post-euro period, as in table 4, the estimated coefficients $(\hat{g})$ for the MSCI world market index become highly significant (in 14-out-of-15 industries) with negative coefficients for almost all the industries (except for materials, software \& services, and technology hardware \& equipment).

Tables 6 and 7 present the results for the full extended model with interaction terms in equation (6) with respect to sectors and industries, respectively. Table 6 shows that the estimated coefficients on the interaction variable between Swedish excess sector returns and exchange rate shocks $(\hat{e})$ are significant at the $10 \%$ level or lower for 5-out-of-6 sectors in the post-euro period but for only one sector in the pre-euro period. In the post-euro period, three significant sectors have negative signs and two have positive signs. Positive signs on the estimated coefficient $\hat{e}$ imply that the positive (integrated) relation

12. We should note that the negative exchange rate exposures in the pre-euro period for the financial sector reported in tables 4 and 5 are probably driven by the insurance company Sampo. This company was included in the financial sector but not in any industry group, as there was no comparable Swedish counterpart. The median market capitalization for Sampo was $80 \%$ of the financial sector total market capitalization during our period.

13. Since there is only one comparable company in both countries in this industry, our results may well not be representative for this industry group as a whole. 


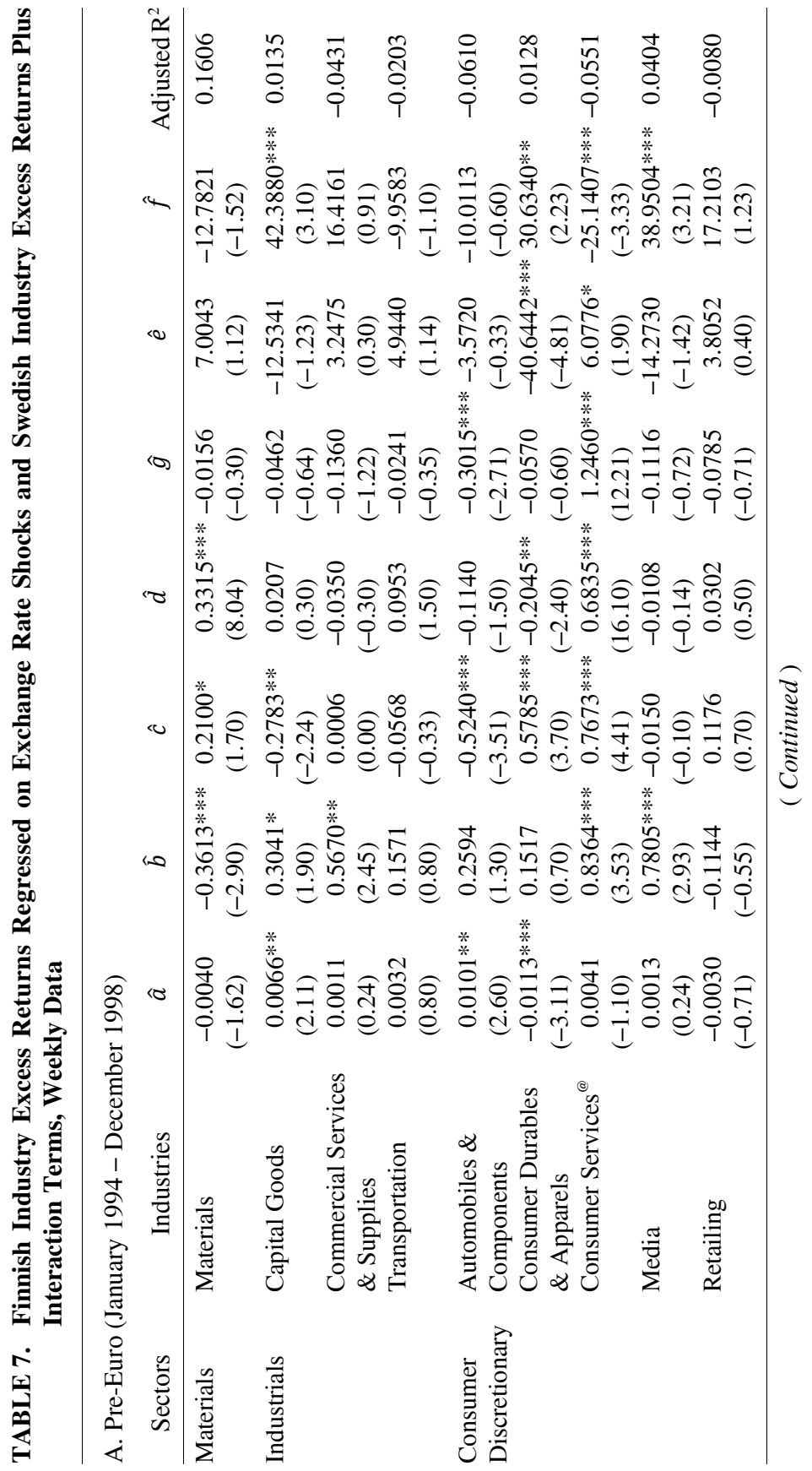




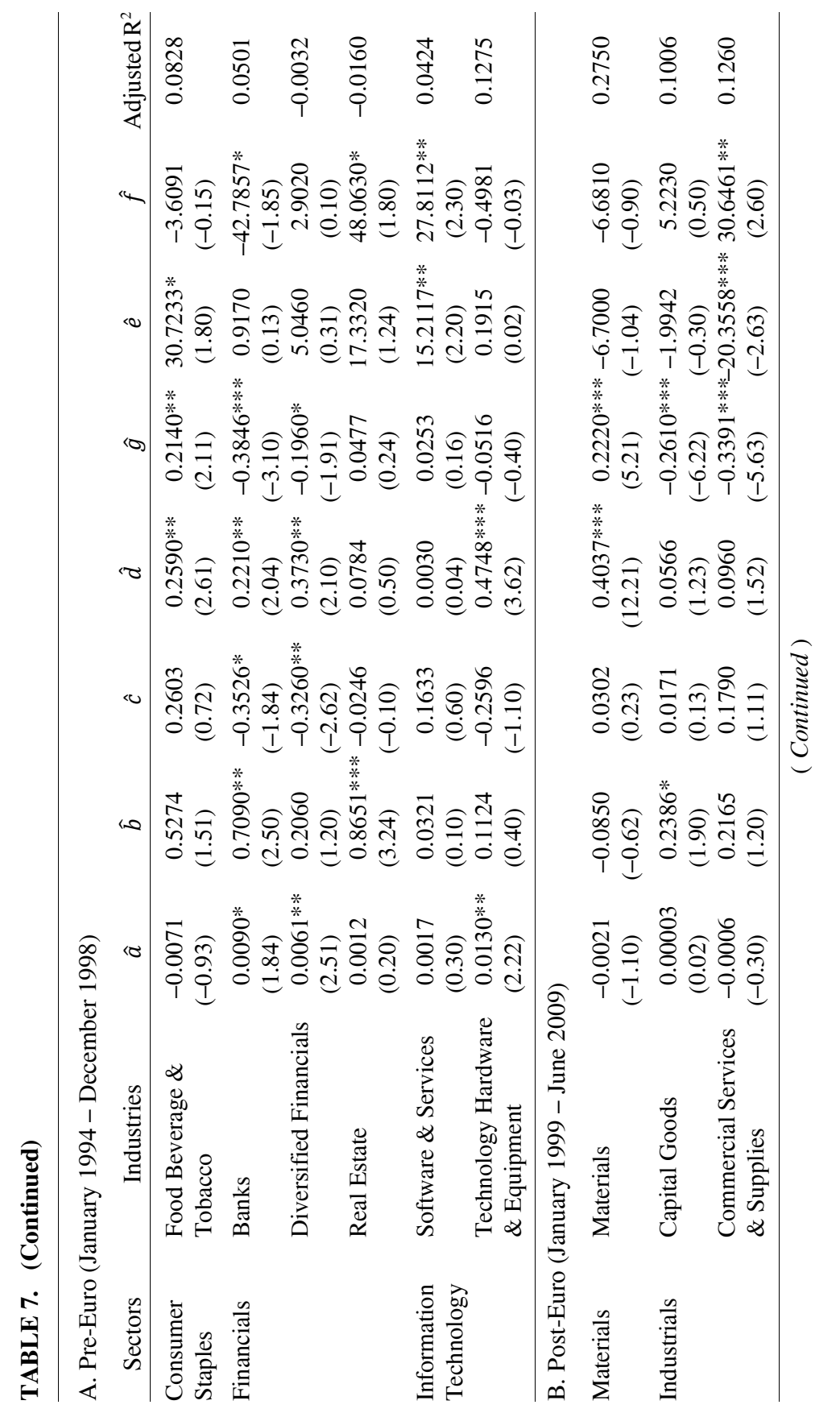




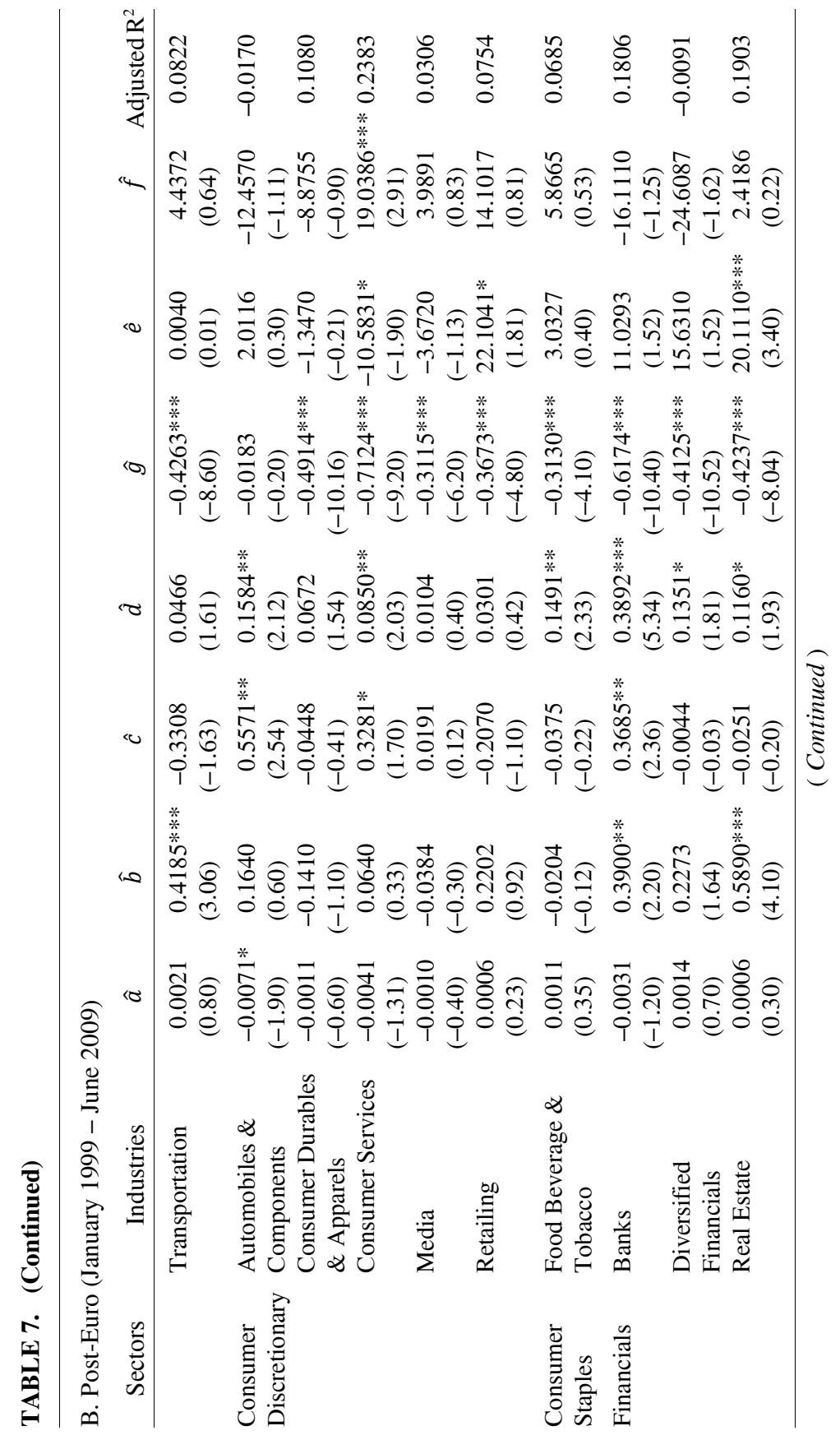




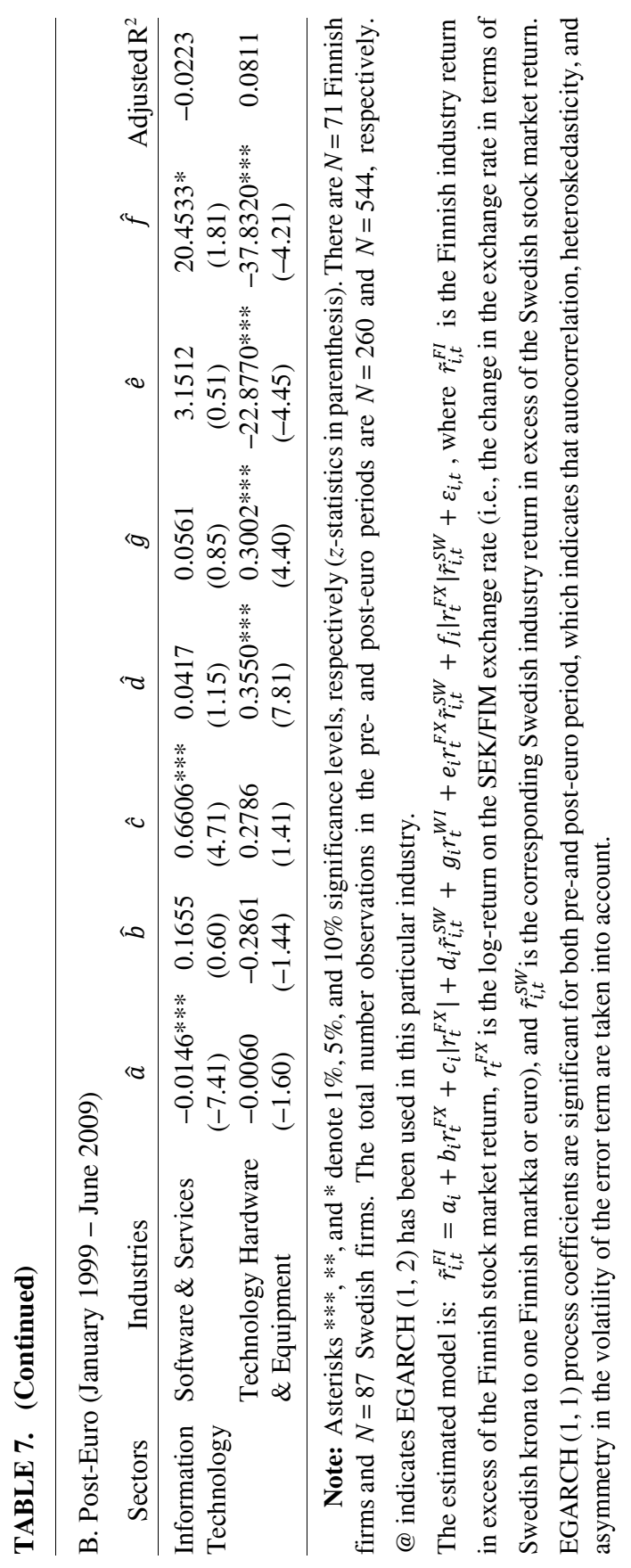


between Finnish and Swedish stocks increased when the euro appreciated against the krona, and vice versa for negative signs. This interaction effect supports the forex competition hypothesis, as exchange rates shocks alter the competitive relationship between Finnish and Swedish sectors (i.e., increasing or decreasing their integration). Additionally, evidence for interaction between Swedish excess industry returns and exchange rate volatility as reflected by its estimated coefficient $(\hat{f})$ is fairly weak, with only two significant sector coefficient(s) in both pre-and post-euro periods.

The results for the industry groups in table 7 are similar for the most part, with only 4-out-of-15 significant estimated $\hat{e}$ coefficients in the pre-euro period compared with 5-out-of-15 significant coefficients in the post-euro period. Unlike table 6 , the estimated coefficients on the interaction between Swedish excess industry returns and exchange rates volatility $(\hat{f})$ are moderately significant, with 4(7)-out-of-15 significant industry coefficients in the post- (pre-) euro period. Even so, it should be noted that the significant positive linear excess exchange exposure $(\hat{b})$ for the food beverage $\&$ tobacco industry in the pre-euro period reported in table 5 is probably an approximation for nonlinear exposure, as it becomes insignificant when nonlinearity is introduced in table 7 . Furthermore, regarding the world market index coefficients $(\hat{g})$, the results are similar as shown earlier in tables 4,5 , and 6.

As in Griffin and Stulz, the average adjusted $R^{2}$ values in tables 6 and 7 are quite similar to those without interaction terms in tables 4 and 5; thus, the magnitude of conditional exchange rate effects on Finnish and Swedish stock return co-movements is not large. However, since excess market returns should be unpredictable in an efficient market, low $R^{2}$ values are not unexpected. More importantly, given that multicollinearity arising from the inclusion of all constitutive terms in multiplicative models increases the size of standard errors and downward biases the significance of interaction variables (see Brambor, Clark and Golder, 2005), the significance of interaction variables is interpreted to mean that industries' relative integration is affected by exchange rate movements to some degree.

To further investigate the effect of exchange rate shocks on the relation between Finnish and Swedish sectors' and industries' excess stock returns, the full extended model in equation (8) is utilized to compute the following total marginal effect of Swedish excess stock returns: 


$$
\partial \hat{r}_{i, t}^{F I} / \partial \hat{r}_{i, t}^{S W}=d_{i}+e_{i} r_{t}^{F X}+f_{i}\left|r_{t}^{F X}\right| .
$$

Comparing this total marginal effect to the unconditionally estimated coefficient on Swedish excess stock returns $(\hat{d})$ enables a better understanding of the conditional influence of exchange rates shocks on the Finnish/Swedish stock return relation. Equation (7) is estimated at mean, median, maximum and minimum values of exchange rate shocks $r_{t}^{F X}$ for sectors and industries in tables 8 and 9.

The sector results in table 8 demonstrate that interaction exchange rate shocks noticeably change the relation between Finnish and Swedish excess stock returns. For example, in the pre-euro period the estimated $\hat{d}$ for the industrial sector was not significant with a coefficient of only 0.028 , but the total marginal effect (at mean $r_{t}^{F X}$ ) is 0.310 , or more than 10 times the unconditional effect of Swedish returns on Finnish returns. Strikingly, in some sectors, such as consumer discretionary and financials in the pre-euro period as well as consumer discretionary and information technology in the post-euro period, the estimated $\hat{d}$ is positive implying market integration but the total marginal effect at the mean forex return $r_{t}^{F X}$ is negative suggesting sector competitiveness (i.e., the marginal effects in the financials in pre-euro and information technology sector in the post-euro period are statistically significant). Table 9 gives similar results for industries. Note that, in the pre-euro period the total marginal effects are negative in the transportation, automobile \& components and banking industries (i.e., statistically significant for the banking industry). In the post-euro period, the effect is negative for automobiles \& components, consumer durables \& apparels, diversified financials, and technology hardware \& equipment industries (i.e., statistically significant only for the technology hardware $\&$ equipment industries). Altogether, in the pre-euro period, 8-out-of-15 industries have statistically significant marginal effects at the mean forex return $r_{t}^{F X}$. However, in the post-euro period, 6-out-of-15 industries have significant marginal effects at the mean forex return, which indicates market integration still exists.

Taking as an example the technology hardware \& equipment industry group in table 9 , in the pre-euro period a significant total marginal competitiveness effect (at mean $r_{t}^{F X}$ ) of 0.465 is found, whereas in the post-euro period it is significant but with opposite sign at -0.186 . Hence, the technology hardware \& equipment industry 


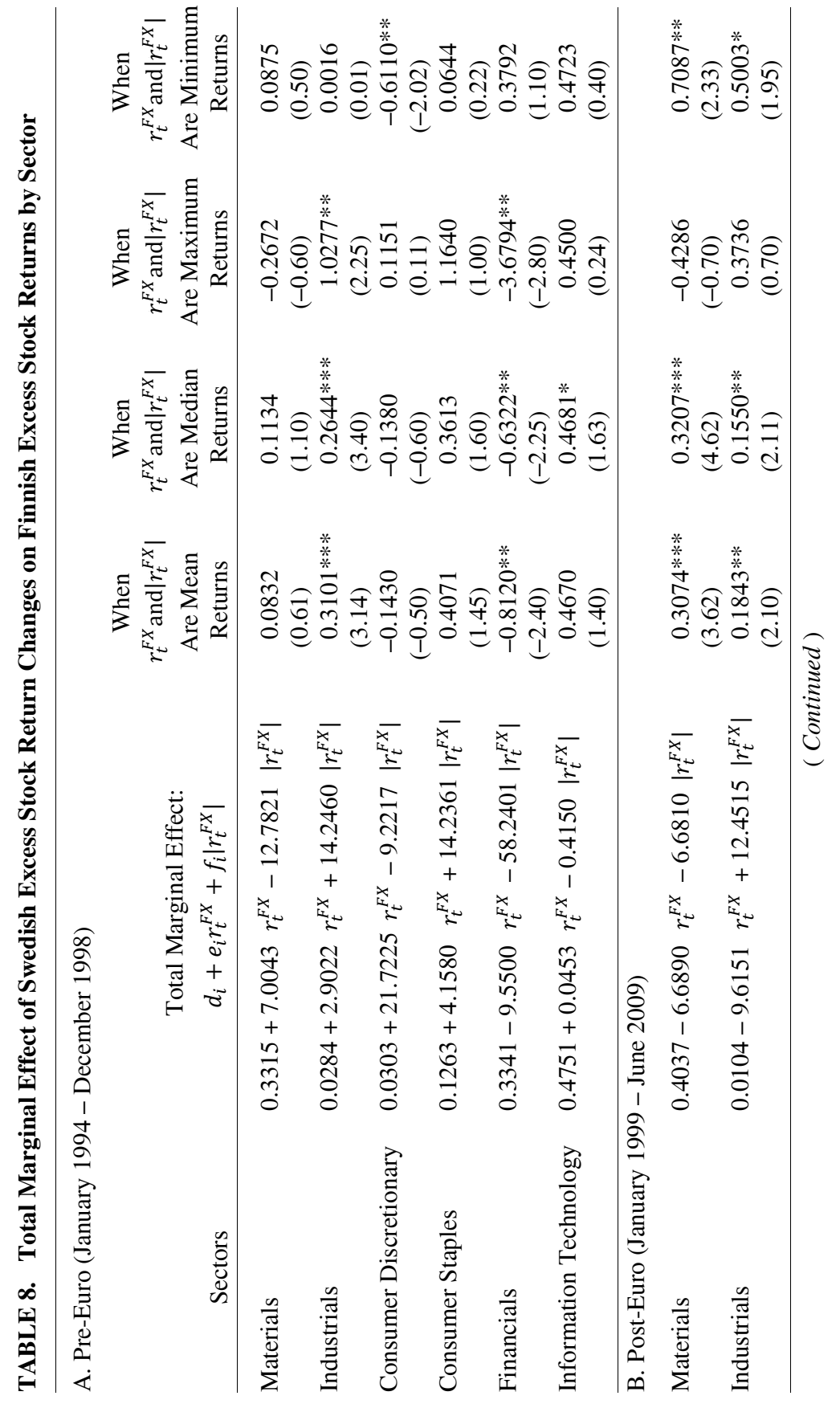




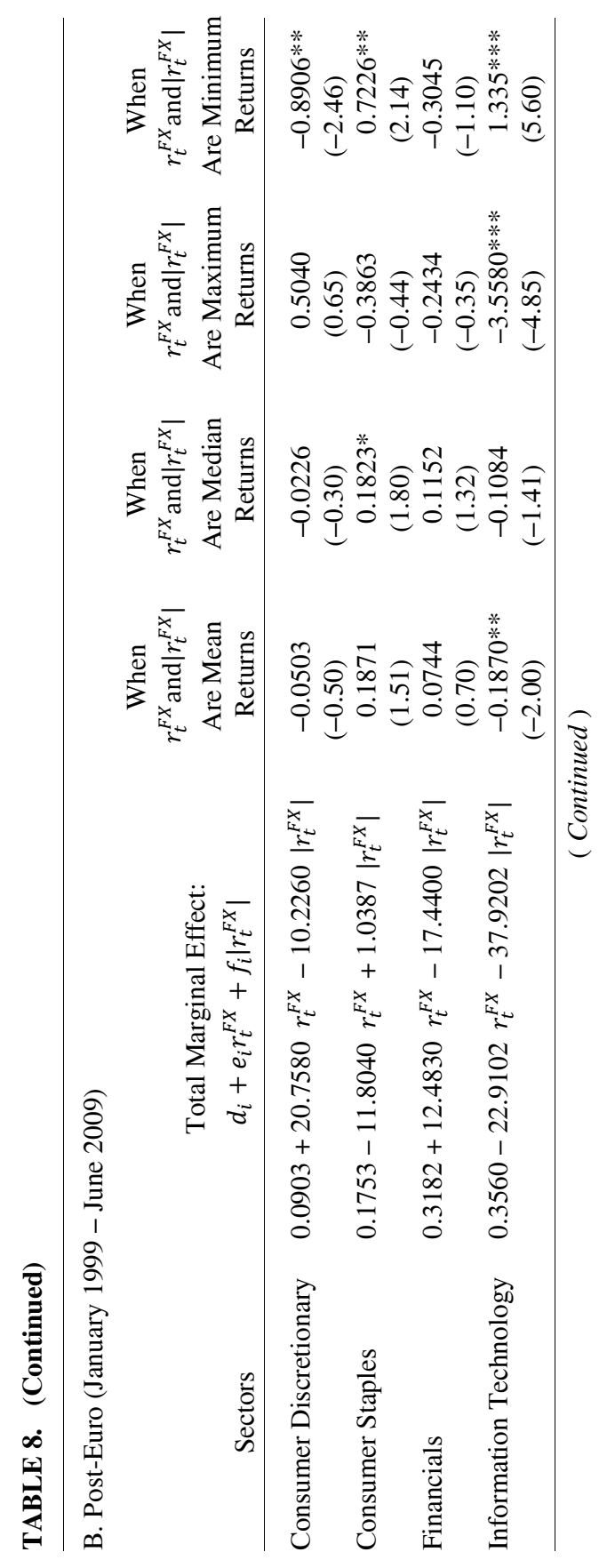




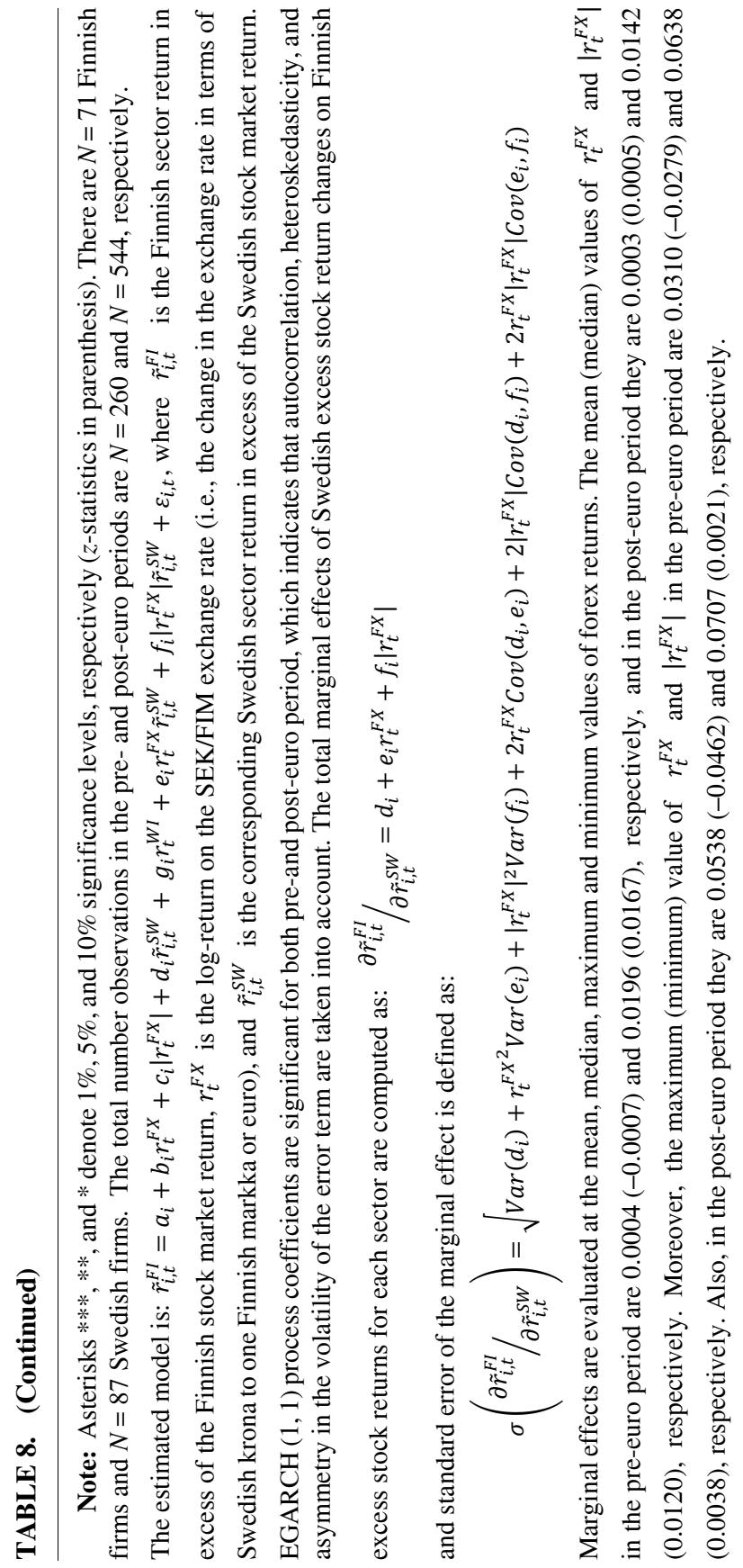




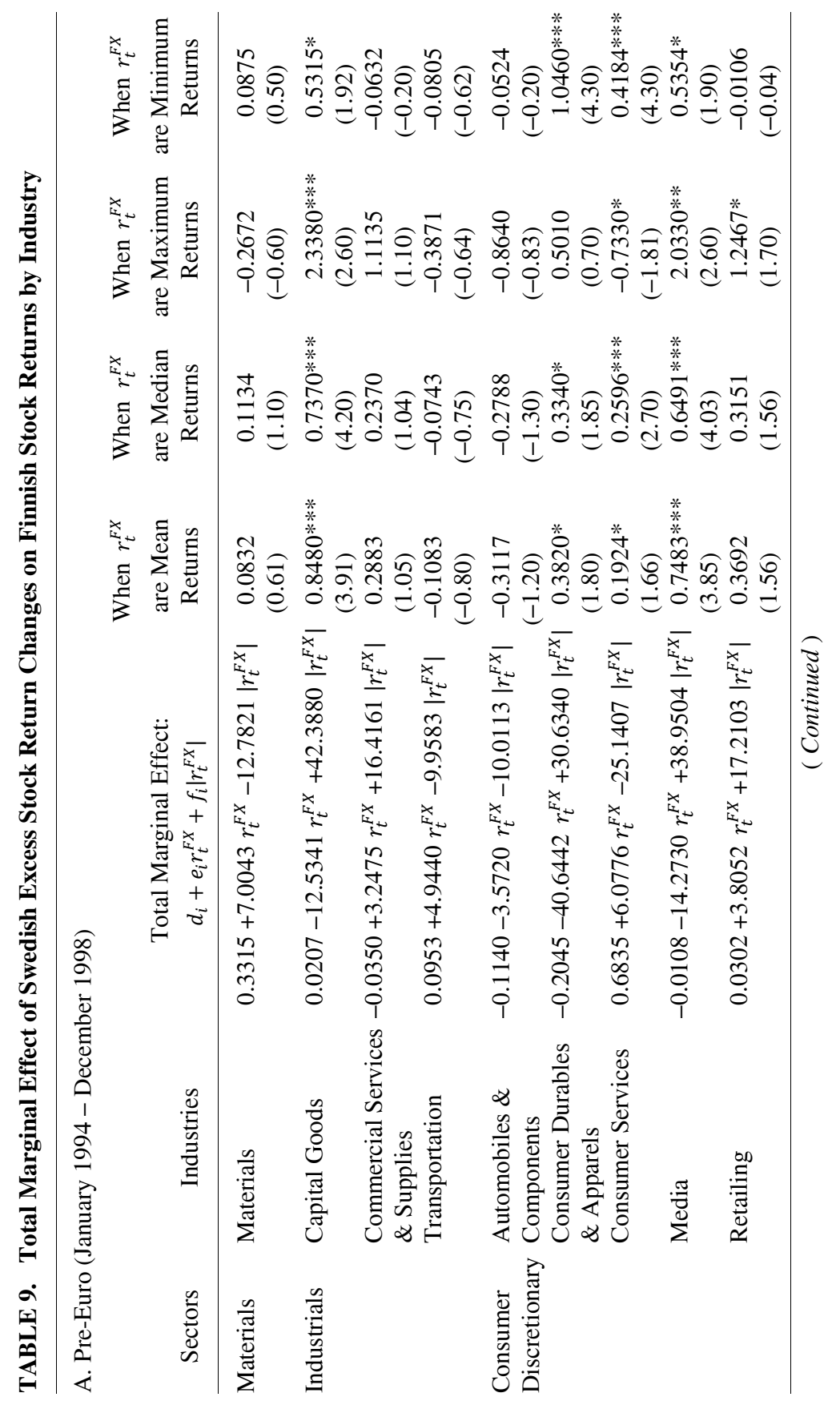




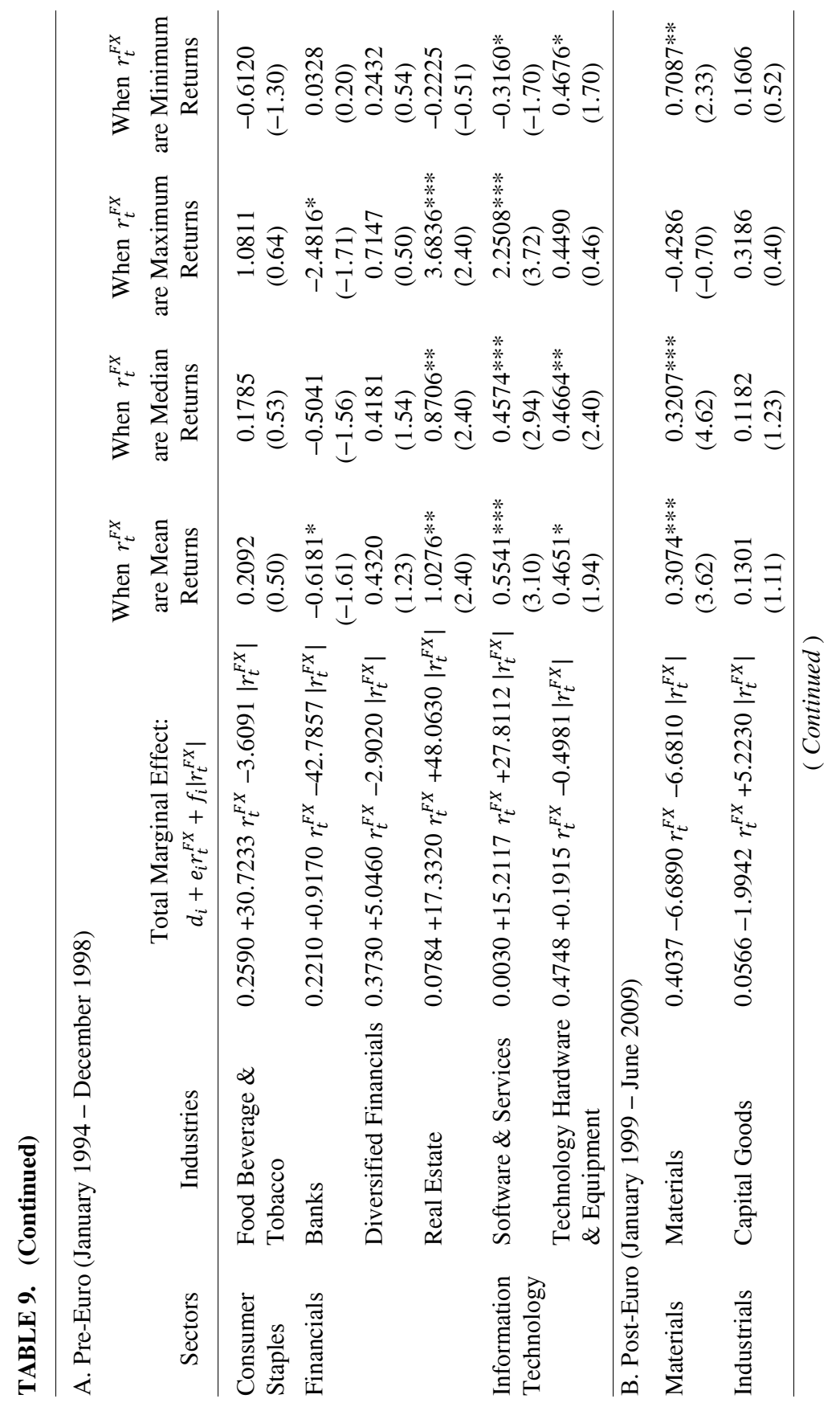




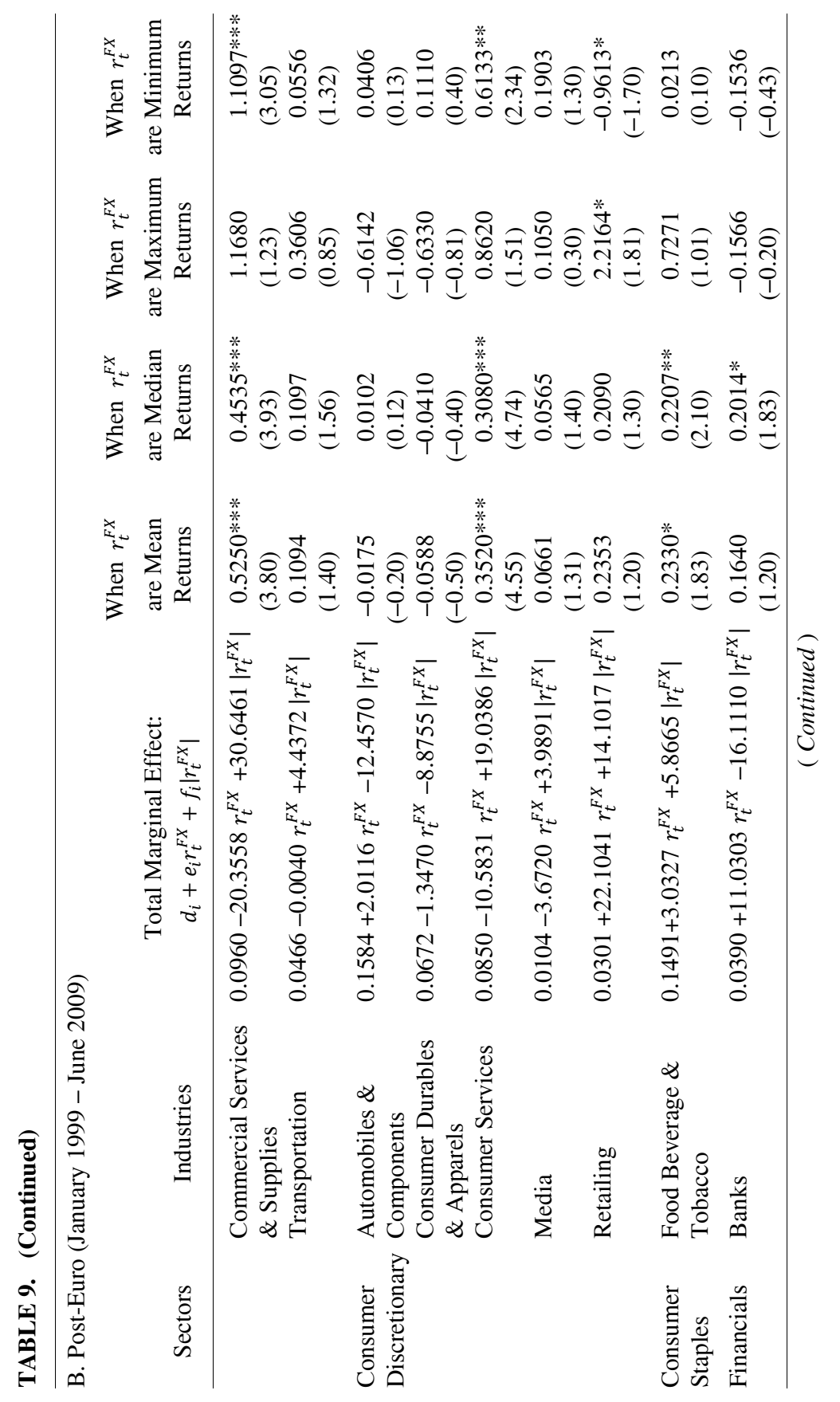




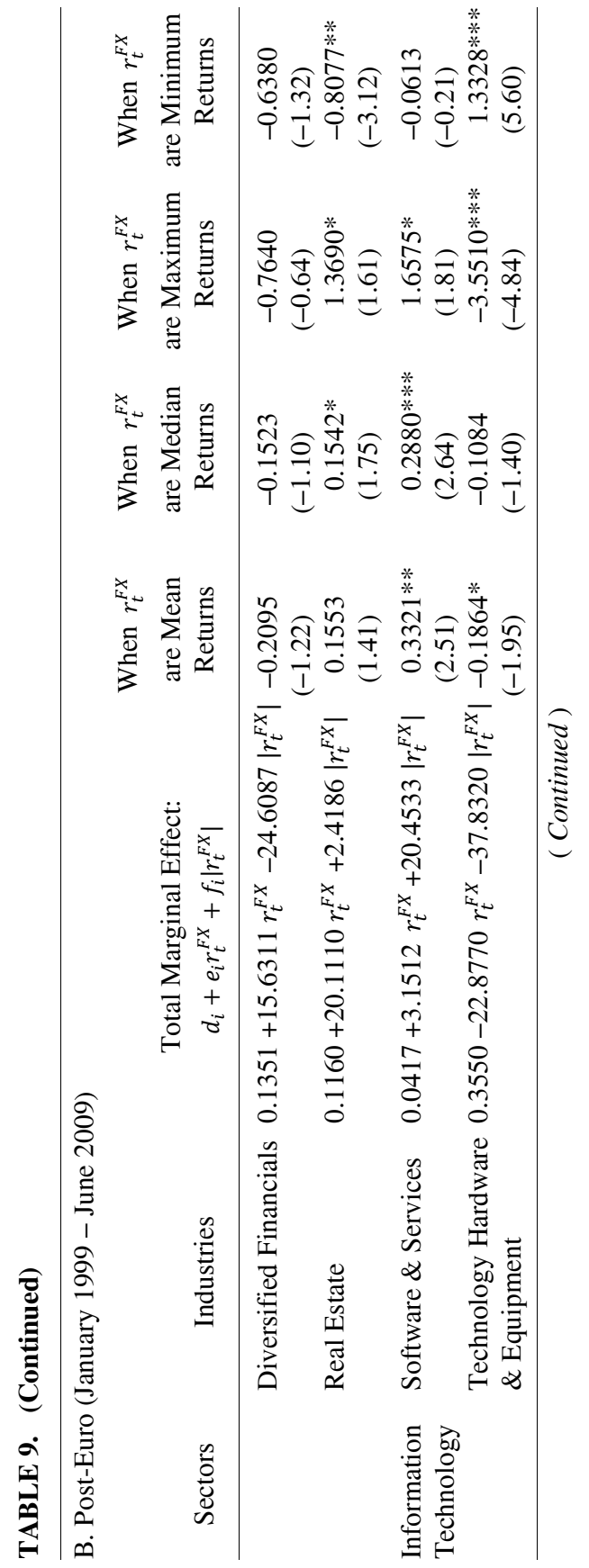




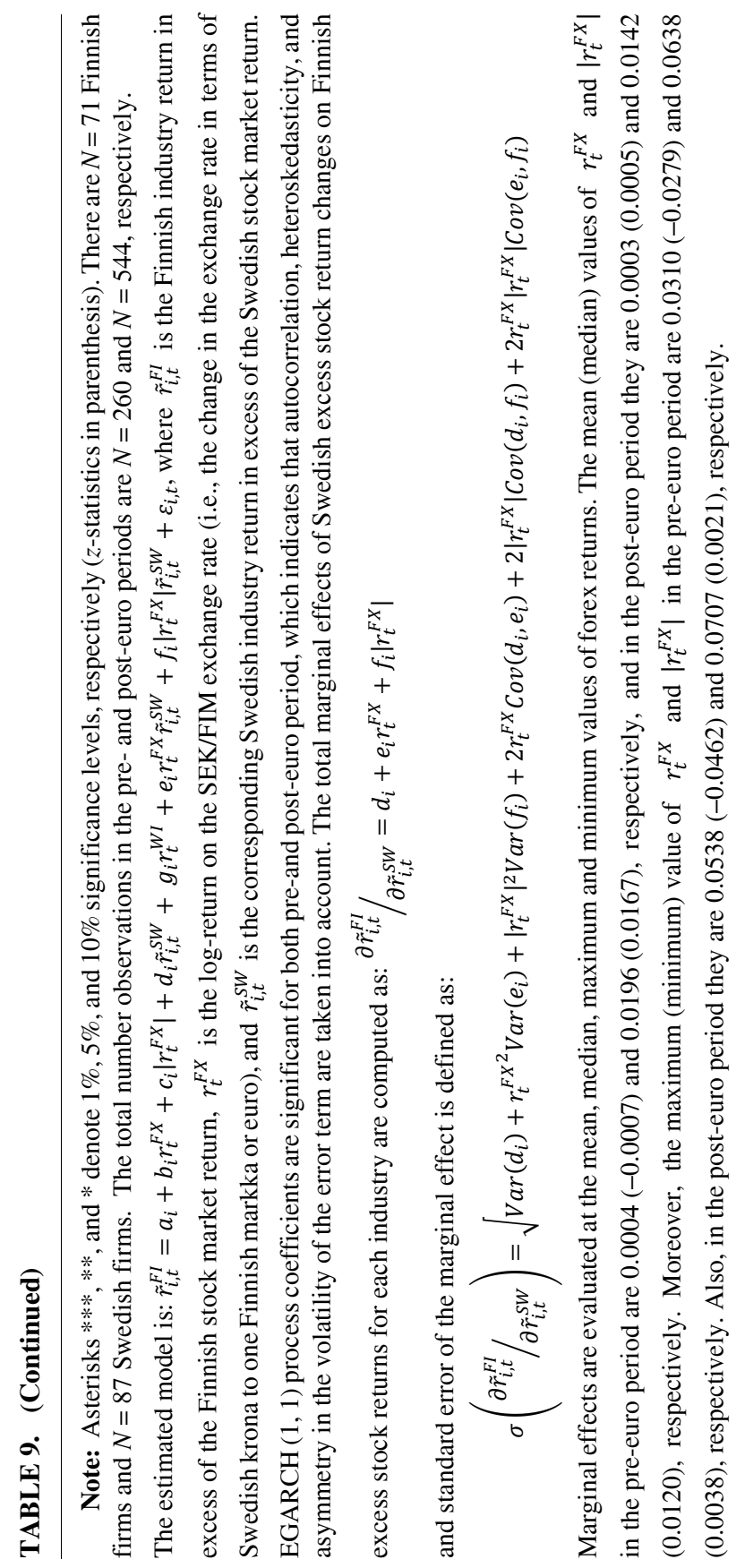


became a competitive industry group in the post-euro period. An increase of 1 percent in the Swedish corresponding industry return would impose a competitiveness effect of about -0.20 percent at the mean level of exchange rate returns. At the maximum level of observed exchange rate returns, the results indicate that for a 1 percent Swedish industry return there is a negative competitiveness effect of about -3.6 percent. On the other hand, at the minimum level of observed exchange rate returns, a 1 percent return on the Swedish industry the effect is positive and statistically significant with an integration effect of +1.33 percent. In sum, these results clearly indicate some degree of conditional competitiveness associated with exchange rate changes.

Highlighting the aforementioned discussion of minimum and maximum exchange rate levels, in many weeks the total marginal effects are considerably greater than those reported at mean and median exchange rate levels, in tables 8 and 9. Total marginal effects are estimated there using the mean (and median) values of exchange rate shocks $\left(r_{t}^{F X}\right)$, which are very small, viz., $0.00035(-0.00066)$ and 0.00025 (0.00046) in the pre- and post-euro periods, respectively, due to the near-zero, stationary properties of exchange rate returns. By comparison, the standard deviations of weekly exchange rate returns were 0.0105 and 0.0091 in the pre- and post-euro periods, respectively, or over 35 times the magnitudes of their mean values. As such, negative $\hat{e}$

and $\hat{f}$ coefficients for interaction variables can readily produce negative total marginal effects. Casual inspection of these coefficients' signs in table 8 and 9 suggests that negative total marginal effects are more prevalent than implied by mean exchange rate shocks. Overall, given dependencies between exchange rate movements and stock co-movements in the two countries, indicating increased competitive sensitivity of Finnish firms in some sectors and industry groups to exchange rate movements in the post-euro period compared with the pre-euro period, which is consistent with the more general finding of increasing forex sensitivity in the post-euro period shown in table 2.

\section{Conclusion}

This study has attempted to test the forex competition hypothesis that posits relative changes in competitiveness between similar firms in different countries in response to exchange rate changes. The study focuses on the case of Finland due to its close competitive relationship 
with Sweden. Both countries have small, export-oriented economies that compete head-to-head due to similarities in industry structure and export markets. Finland adopted the euro in 1999, whereas Sweden retained the krona as its national currency. This dichotomy affords an opportunity to gain some insight into how the euro affected the competitiveness of EMU countries relative to non-EMU countries.

Using matched samples of Finnish and Swedish firms in the period 1994 to 2009, controlled tests by sector and industry show that Finnish stocks' value tend to rise as the home currency depreciates against the Swedish krona. This sensitivity increased considerably in the post-euro period after 1999 compared with the pre-euro period. Further tests revealed that Finnish sectors and industries positively co-move with their Swedish counterparts, which implies market integration rather than competitiveness. In other words, in the post-euro, there is more integration between sectors or industries in Finland and Sweden, rather than more sector or industry competitiveness in the sense that a sector in one country benefits while in the other loses. While the two countries' stock returns are unconditionally integrated, exchange rate movements can substantively alter their co-movement, especially in the post-euro period with heightened sensitivity to exchange rates and associated volatility. These results are based on weekly excess market returns. Similar regressions were tested using daily time series with almost identical results. Furthermore, while excess-returns over the market returns for Finnish and Swedish markets were used, results for total returns (including dividends) were almost the same. Like Griffin and Stulz (2001), industry effects outweigh exchange rate effects on stock returns. However, based on total marginal effects of Swedish stock returns on Finnish stock returns, competitive exchange rate effects do appear to exist in the case of Finland for some sectors and industry groups. This indicates that countries with small, open economies, such as Finland, can be prone to exchange rate movements that (dis)advantage their firms relative to competing firms in other countries. However, there seems to be less observable exposure as previously explained by Bartram, Brown and Minton (2010), which may be due to financial hedging with foreign debt, usage of forex derivatives and/or to some extent pass-through of exposure to the customers. By implication, firms in other export nations may well be exposed to competitive pressures from exchange rate shocks, even after controlling world market integration. Further research is recommended to corroborate the findings and document the competitive effects of 
exchange rate fluctuations on firms. As cited in the introduction, the effects of the euro on export-oriented countries (e.g., Greece, Portugal, Spain, and Italy) in the eurozone in recent years would be particularly interesting.

Accepted by: Prof. P. Theodossiou, Editor-in-Chief, April 2013

\section{References}

Adler, M., and Dumas, B. 1980. The exposure of long-term foreign currency bonds. Journal of Financial and Quantitative Analysis 15: 973-994.

Adler, M., and Dumas, B. 1983. International portfolio choice and corporate finance: A synthesis. Journal of Finance 38: 925-984.

Adler, M., and Dumas, B. 1984. Exposure to currency risk: Definition and measurement. Financial Management 13: 41-50.

Allayannis, G., and Ihrig, J. 2001. Exposure and markups. Review of Financial Studies 14: 805-835.

Antell, J., and Vaihekoski, M. 2007. International asset pricing models and currency risk: Evidence from Finland 1970-2004. Journal of Banking and Finance 31: 2571-2590.

Badinger, H., and Breuss, F. 2009. Country size and the trade effects of the euro. Review of World Economies 145: 207-223.

Baldwin, R.E. 2006. The euro's trade effects. European Central Bank Working Paper no. 594. Frankfurt am Main, Germany: European Central Bank.

Barr, D.; Breedon, F.; and Miles, D. 2003. Life on the outside: Economic conditions and prospects outside Euroland. Economic Policy 18: 573-613.

Bartov, E., and Bodnar, G. M. 1994. Firm valuation, earnings expectations, and the exchange-rate exposure effect. Journal of Finance 49: 1755-1785.

Bartram, S. M. 2007. Corporate cash flow and stock price exposures to foreign exchange rate risk. Journal of Corporate Finance 13: 981-994.

Bartram, S. M., and Karolyi, G. A. 2006. The impact of the introduction of the euro on foreign exchange rate risk exposures. Journal of Empirical Finance 13: 519-549.

Bartram, S.M.; Brown, G.W.; and Minton B.A. 2010. Resolving the exposure puzzle: The many facets of exchange rate exposure. Journal of Financial Economics 95: 148-173.

Bodnar, G. M.; Dumas, B.; and Marston, R. C. 2002. Pass-through and exposure. Journal of Finance 57: 199-231.

Bodnar, G. M., and Wong, M. H. F. 2003. Estimating exchange rate exposures: Issues in model structure. Financial Management 32: 35-67.

Brambor, T.; Clark, W. R.; and Golder, M. 2005. Understanding interaction models: Improving empirical analyses. Political Analysis 14: 63-82. 
Bris, A.; Koskinen, Y.; and Nilsson, M. 2006. The real effects of the euro: Evidence from corporate investments. Review of Finance 10: 1-37.

Bris, A.; Koskinen, Y.; and Nilsson, M. 2009. The euro and corporate valuations. Review of Financial Studies 22: 3171-3209.

Bun, M. J. G., and Klaassen, F. J. G. M. 2007. The euro effect on trade is not as large as commonly thought. Oxford Bulletin of Economics and Statistics 69: 473-496.

Chen, J.; Naylor, M.; and Lu, X. 2004. Some insights into the foreign exchange pricing puzzle: Evidence from a small open economy. Pacific-Basin Finance Journal 12: 41-46.

De Santis, G., and Gérard, B. 1998. How big is the premium for currency risk. Journal of Financial Economics 49: 375-412.

De Santis, G.; Gerard, B.; and Hillion, P. 2003. The relevance of currency risk in the EMU. Journal of Economics and Business 55: 427-462.

Doidge, C.; Griffin, J.; and Williamson, R. 2006. Measuring the economic importance of exchange rate exposure. Journal of Empirical Finance 13: $550-576$.

Dominguez, K. M. E., and Tesar, L. L. 2006. Exchange rate exposure. Journal of International Economics 68: 188-218.

Dumas, B., and Solnik, B. 1995. The world price of foreign exchange risk. Journal of Finance 50: 445-479.

Entorf, H.; Moebert, J.; and Sonderhof, K. 2007. The foreign exchange rate exposure of nations. ZEW Discussion Paper 07-005. Manheim, Germany: Centre of European Economic Research.

Griffin, J. M., and Stulz, R. M. 2001. International competition and exchange rate shocks: A cross-country industry analysis of stock returns. Review of Financial Studies 14: 215-241.

$\mathrm{He}$, J., and Ng, L. K. 1998. The foreign exchange exposure of Japanese multinational corporations. Journal of Finance 53: 733-753.

Hardouvelis, G.; Malliaropoulos, D.; and Priestley, R. 2006. EMU and European stock market integrations. Journal of Business 79: 369-392.

Jonung, L., and Sjöholm, F. 1999. Should Finland and Sweden form a monetary union?. The World Economy 22: 683-700.

Jorion, P. 1990. The exchange-rate exposure of U.S. multinationals. Journal of Business 63: 331-345.

Jorion, P. 1991. The pricing of exchange rate risk in the stock market. Journal of Financial and Quantitative Analysis 26: 363-376.

Knif, J.; Pynnönen, S.; and Luoma, M. 1995. An analysis of lead-lag structures using a frequency domain approach: Empirical evidence from the Finnish and Swedish stock markets. European Journal of Operational Research 81: 259-270.

Knif, J., and Pynnönen, S. 2001. Local and global price memory of international stock markets, Chapter 11:189-208, in International Securities, Volume 2, Part II, Interactions of Financial Markets and Price Dynamics edited by G. 
Philippatos and G. Koutmos. UK: Edgar Elger Publishing Inc.

Kolari, J. W.; Moorman, T. C.; and Sorescu, S. M. 2008. Foreign exchange risk and the cross-section of stock returns. Journal of International Money and Finance 27:1074-1097.

Koutmos, G., and Knif, J. 2011. Exchange rate exposure in the pre- and post-Euro periods: evidence from Finland. The European Journal of Finance 17: 661-674.

Micco, A.; Stein, E.; and Ordóñez, G. 2003. The currency union effect on trade: Early evidence from EMU. Economic Policy 18: 315-356.

Muller, A., and Verschoor, W. F. C. 2006. European foreign exchange risk exposure. European Financial Management 12:195-220.

Mundell, R. A. 1961. A theory of optimum currency areas. American Economic Review 51: 509-517.

Mundell, R. A. 1973. Uncommon arguments for common currencies. In H.G. Johnson and A.K. Swoboda (eds). The Economics of Common Currencies: Proceedings of the Madrid Conference on Optimum Currency Areas. London: George Allen \& Unwin Ltd.

Mundell, R. A. 2000. Currency areas, volatility and intervention. Journal of Policy Modeling 22: 281-299.

Nguyen, H.; Faff, R.; and Marshall, A. 2007. Exchange rate exposure, foreign currency derivatives and the introduction of the euro: French evidence. International Review of Economics and Finance 16: 563-577.

Pynnönen, S., and Knif, J. 1998. Common long- and short- term price memory in two Scandinavian stock markets. Applied Financial Economic 8: 257-265.

Rees, W., and Unni, S. 2005. Exchange rate exposure among European firms: Evidence from France, Germany and the UK. Accounting and Finance 45: 479-497.

Sentana, E. 2002. Did the EMS reduce the cost of capital?. The Economic Journal 112: 786-809.

Tenreyro, S., and Barro, R. J. 2003. Economic effects of currency unions. NBER Working Paper No. 9435.Cambridge, Mass.: National Bureau of Economic Research.

Vassalou, M. 2000. Exchange rate and foreign inflation risk premiums in global equity returns. Journal of International Money and Finance 19: 433-470.

Williamson, R. 2001. Exchange rate exposure and competition: Evidence from the automotive industry. Journal of Financial Economics 59: 441-475. 